UNIVERSIDADE DE BRASÍLIA

FACULDADE DE AGRONOMIA E MEDICINA VETERINÁRIA

PROGRAMA DE PÓS-GRADUAÇÃO EM AGRONOMIA

CARACTERIZAÇÃO AGRONÔMICA DE PLANTAS E TEOR DE CAROTENOIDES TOTAIS DE GENÓTIPOS DE MILHO EM SISTEMA AGROECOLÓGICO

GLAUCO JOSÉ JÚNIOR

DISSERTAÇÃO DE MESTRADO

EM AGRONOMIA

BRASÍLIA/DF

Outubro/2014 


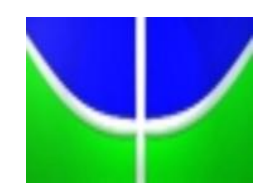

UNIVERSIDADE DE BRASÍLIA

FACULDADE DE AGRONOMIA E MEDICINA VETERINÁRIA PROGRAMA DE PÓS-GRADUAÇÃO EM AGRONOMIA

\title{
CARACTERIZAÇÃO AGRONÔMICA DE PLANTAS E TEOR DE CAROTENOIDES TOTAIS DE GENÓTIPOS DE MILHO EM SISTEMA AGROECOLÓGICO
}

\author{
GLAUCO JOSÉ JÚNIOR \\ ORIENTADOR: CARLOS ROBERTO SPEHAR \\ COORIENTADOR: ALTAIR TOLEDO MACHADO \\ DISSERTAÇÃO DE MESTRADO \\ EM AGRONOMIA
}

PUBLICAÇÃO: 076/2014

BRASÍLIA/DF

Outubro/2014 


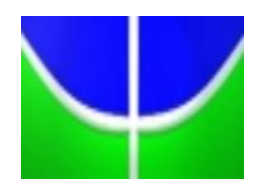

UNIVERSIDADE DE BRASÍLIA

FACULDADE DE AGRONOMIA E MEDICINA VETERINÁRIA PROGRAMA DE PÓS-GRADUAÇÃO EM AGRONOMIA

\section{CARACTERIZAÇÃO AGRONÔMICA DE PLANTAS E TEOR DE CAROTENOIDES TOTAIS DE GENÓTIPOS DE MILHO EM SISTEMA AGROECOLÓGICO}

GLAUCO JOSÉ JÚNIOR

DISSERTAČ̃̃O DE MESTRADO SUBMETIDA AO PROGRAMA DE PÓSGRADUAÇÃ̃O EM AGRONOMIA, COMO PARTE DOS REQUISITOS NECESSÁRIOS À OBTENÇÃO DO GRAU DE MESTRE EM AGRONOMIA.

APROVADA POR:

CARLOS ROBERTO SPEHAR, Dr., Unb/CPF: 122.262.116-91/spehar@unb.br

MARCELO FAGIOLI, Dr., UnB/729.409.306-78/mfagioli@unb.br

LUCIANO NASS, Dr., Embrapa/610.490.779-20/luciano.nass@embrapa.br

BRASÍLIA/DF, 31 DE OUTUBRO DE 2014. 


\section{FICHA CATALOGRÁFICA}

José Júnior, Glauco

Caracterização agronômica de plantas e teor de carotenoides totais de genótipos de milho em sistema agroecológico, 2014. 74f. il.

Dissertação de Mestrado (M) - Universidade de

Brasília/Faculdade de Agronomia e Medicina Veterinária, 2014.

1. Milho. 2. Melhoramento Participativo. 3. Sistemas Agroecológicos.

4. Diversidade Genética do Milho. 5. Carotenoides

\section{REFERÊNCIA BIBLIOGRÁFICA}

JOSÉ JÚNIOR, G. Caracterização agronômica de plantas e teor de carotenoides totais de genótipos de milho em sistema agroecológico. Brasília: Faculdade de Agronomia e Medicina Veterinária, Universidade de Brasília, 2014, 74f. Dissertação de Mestrado.

\section{CESSÃO DE DIREITOS}

NOME DO AUTOR: Glauco José Júnior

TÍTULO DA DISSERTAÇÃO: Caracterização agronômica de plantas e teor de carotenoides totais de genótipos de milho em sistema agroecológico.
GRAU: Mestre
ANO: 2014

É concedida à Universidade de Brasília de Brasília permissão para reproduzir cópias desta dissertação de mestrado para única e exclusivamente propósitos acadêmicos e científicos. O autor reserva para si os outros direitos autorais, de publicação. Nenhuma parte desta dissertação de mestrado pode ser reproduzida sem a autorização por escrito do autor. Citações são estimuladas, desde que citada à fonte.

Nome: Glauco José Júnior

CPF: 214.957.918-90

Endereço: Condomínio Quintas do Sol quadra 07 casa 02-A, Jardim Botânico, DF. CEP 71.680-370

Tel. (61) 3299-7000 / (61) 8298-7654

Email: glaucojjunior@hotmail.com 
AOS MEUS QUERIDOS PAIS E AVÓS,

PELO APOIO E ENSINAMENTOS

DA VIDA,

DEDICO

À MINHA ESPOSA JANAÍNA E

AO MEU FILHO GUSTAVO, OFEREÇO 


\section{AGRADECIMENTOS}

Primeiramente a Deus, criador do universo, pois sem ele nada deste sonho se tornaria realidade.

Aos meus pais Lígia e Glauco e aos meus avôs Vivaldo, Lourdes, Egnes e Arley por terem por terem me proporcionado as oportunidades necessárias para a conclusão desse trabalho. Agradeço aos meus irmãos Camila, Ana Carolina, Felipe, pelo apoio constante e, em especial ao Auler, por sua ajuda direta nos trabalhos de campo. Ao restante da família, em especial ao meu tio Fernando Vilarinho, pelos conselhos e confiança.

À minha querida e amada esposa Janaína, pois sem ela não teria sido possível a conclusão deste.

Ao meu filho Gustavo que, com apenas quatro meses de vida, me incentivou a concluir este estudo.

Ao Orientador Dr. Carlos Roberto Spehar, pela coordenação, apoio, paciência e ensinamentos durante o curso.

Aos Drs. Altair Toledo Machado e Cynthia Torres de Toledo Machado, referências em pesquisa participativa no mundo, por todos os ensinamentos durante os últimos 12 anos, orientações de estágios e projetos, confiança e amizade.

Ao Dr. Luciano Lourenço Nass, referência mundial em recursos genéticos e melhoramento vegetal, pelas ajudas, orientações e amizade.

Ao professor e amigo Dr. José Ricardo Peixoto, pelos muitos ensinamentos.

Ao Dr. Hermes Jannuzzi, proprietário do Sítio Corujinha e multiplicador da agroecologia, que gentilmente cedeu espaço para o plantio do experimento com toda hospitalidade durante minha permanência em sua propriedade.

Ao Dr. Luiz Antônio Borgo, pelo acolhimento em seu laboratório de análises de alimentos.

À Dra. Nara Oliveira Silva, por todos os ensinamentos e ajuda.

Ao Dr. Marcelo Fagioli, por sua indispensável participação neste trabalho.

À Dra. Juliana Ogliari pela realização das análises dos carotenoides e à M.Sc. Rosenilde por ter realizado todas as extrações e quantificações dos carotenoides, mesmo não tendo nenhum tempo para isso.

À Dra. Michelle Vilela, pelas ajudas estatísticas.

À Primaiz Sementes LTDA, pela contribuição de dados e de sementes. 
À Rosana Lourenço, secretária do Programa de pós-graduação, pelo auxílio, amizade e muita paciência com os mestrandos.

Aos Técnicos Agrícolas Ornélio Guedes e Antônio, Embrapa Cerrados, pelos ensinamentos e apoio neste trabalho, ao Técnico Agrícola Manoel, gerente do Sítio Corujinha e ao Doutorando Márcio, do Laboratório de Análises de Alimentos da UnB.

Aos Amigos da 14 e da Polícia Militar, em especial ao Flávio Damasceno Aragão e ao Dr. Guilherme Dias Moreira, pela ajuda e confiança. 


\section{CARACTERIZAÇÃO AGRONÔMICA DE PLANTAS E TEOR DE CAROTENOIDES TOTAIS DE GENÓTIPOS DE MILHO EM SISTEMA AGROECOLÓGICO.}

\section{RESUMO}

A fome e a hipovitaminose $\mathrm{A}$ são problemas que atingem todo o mundo. $\mathrm{O}$ Melhoramento Participativo de Cultivos pode desempenhar um papel preponderante para promover a diminuição desses dois fatores. O presente trabalho teve como objetivo a caracterização agronômica e a comparação de teores de carotenoides totais em quatro cultivares de milho com base genética distintas, extraídos de seus grãos. Para tal, foram utilizadas as variedades de polinização aberta Sol da Manhã e Eldorado da Embrapa, além dos híbridos simples PZ 240 e triplo PZ 316 da Primaiz Sementes Ltda. Para determinação do teor de carotenoides nos grãos, foi utilizado o método de extração e quantificação de carotenoides, encontrando teores médios de 9,50 $\mu \mathrm{g} \mathrm{g}^{-1}, 4,39 \mu \mathrm{g} \mathrm{g}^{-1}, 3,92 \mu \mathrm{g} \mathrm{g}^{-1}$ e 4,13 $\mu \mathrm{g} \mathrm{g}^{-1}$ nas as variedades Sol da Manhã e Eldorado, e nos híbridos PZ 240 e PZ 316, respectivamente. As análises estatísticas e estimativas de parâmetros genéticos foram realizadas com o auxílio dos softwares GENES e MSTAT, detectando diferença significativa $(\mathrm{P} \geq 0,05)$ para a variedade Sol da Manhã, com superioridade na média do teor de carotenoides. Os valores de produtividade mostraram que houve diferença significativa entre todas as cultivares analisadas. Não houve correlação entre as características produção de grãos, teor de carotenoides totais nos grãos e área da folha da espiga superior com nenhum outro parâmetro estudado. Altos valores de herdabilidade em sentido amplo $\left(\mathrm{H}^{2}\right)$ foram observados na maioria dos caracteres agronômicos avaliados. O uso de adubação rica em termofosfato e compostos de farelos aumentou o valor da relação entre as formas de nitrogênio amoniacal e nitrato, além de terem sido detectados valores expressivos de produção para as quatro cultivares.

Palavras-chave: Zea mays L.; melhoramento participativo; diversidade genética; carotenoides totais. 


\section{AGRONOMIC CHARACTERIZATION OF PLANTS AND TOTAL CAROTENOID CONTENT OF MAIZE GENOTYPES IN AGROECOLOGICAL SYSTEM}

\section{ABSTRACT}

Hunger and not the appropriate levels of vitamin A are problems that affect the entire world. Participatory crop breeding can play a leading role in promoting the reduction of these two factors. This study aimed to evaluate agronomic and comparing levels of total carotenoids in four maize cultivars with different genetic background, taken from their grain. To achieve this, open pollinated varieties Sol da Manhã and Eldorado, a simple hybrid (PZ 240), and a triple (PZ316) were used. To determine the content of carotenoids in the grains, the method of extraction and quantification of carotenoids was used. The average levels detected were 9.50 mg g -1, 4.39 mg g -1, 3.92 mg g -1 and 4.13 mg g -1for the Sol da Manhã and Eldorado varieties, and the hybrids PZ 240 and PZ 316, respectively. Statistical analyses and estimates of genetic parameters were performed with the software GENES and MSTAT, detecting a significant difference $(\mathrm{P} \geq 0.05)$ for the variety Sol da Manhã, with higher average content of carotenoids. The productivity values showed a significant difference among the cultivars analyzed. There were no correlation among the characteristics of grain, total carotenoid content in grain and leaf area of the upper ear with any other parameter studied. High heritability in broad sense (H2) were observed in most of the evaluated agronomic traits. The use of fertilizers rich in compounds thermophosphate and sharps increased the value of the relationship between the forms of ammonia and nitrate, as well as impressive production values for the four cultivars were detected.

Key Word: Zea mays L.; participatory breeding; genetic diversity; total carotenoids. 


\section{SIGLAS}

USDA - Departamento de Agricultura dos Estados Unidos

FAO - Food and Agriculture Organization of the United Nations

Embrapa - Empresa Brasileira de Pesquisa Agropecuária

CIB - Conselho de Informações sobre Biotecnologia

Emcapa - Empresa Capixaba de Pesquisa Agropecuária

IBGE - Instituto Brasileiro de Pesquisa e Estatística

CEASA - Centrais de Abastecimento

VPA - Variedades de Polinização Aberta

MPC - Melhoramento Participativo de Cultivos

HS - Híbrido Simples

HD - Híbrido Duplo

CGC - Capacidade Geral de Combinação

CEC - Capacidade Específica de Combinação

Ci - Capacidade de Combinação

QPM - Quality Protein Maize

ADCC - Associação da Cooperativa Central do Cerrado Caxambu

$\mathrm{N}$ - Nitrogênio

DMI - Degeneração Macular Relacionada à Idade

RPM - Rotação por Minuto

Abs - Absorvância

AC - Coeficiente de extinção molar

$\mu \mathrm{g}$ - Micrograma

ERO - Espécie Reativa do Oxigênio

$\mathrm{CT}$ - Carotenoides totais 


\section{SUMÁRIO}

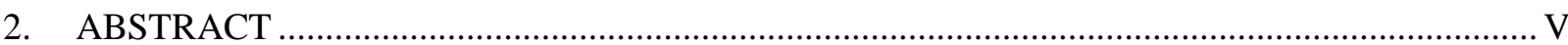

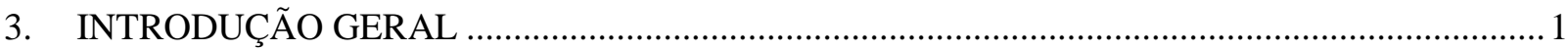

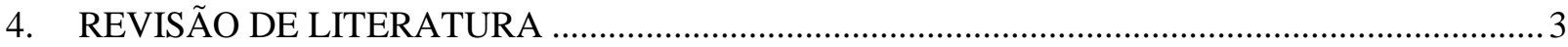

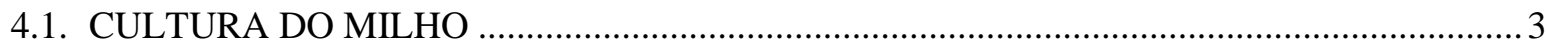

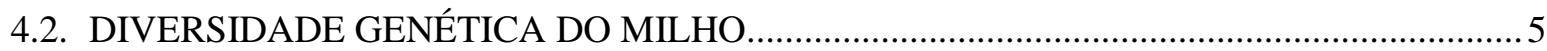

4.3. MANEJO: OBTENÇÃO DE HÍBRIDOS, MELHORAMENTO PARTICIPATIVO E USO

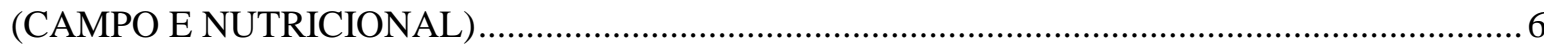

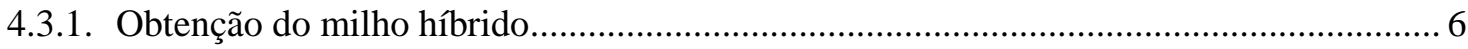

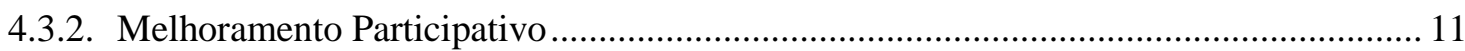

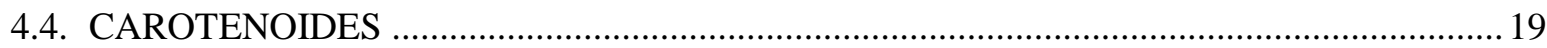

4.5. MANEJO DA DIVERSIDADE GENÉTICA X SISTEMAS DE PRODUÇÃO ......................21

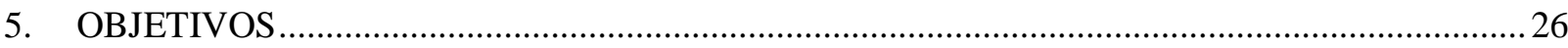

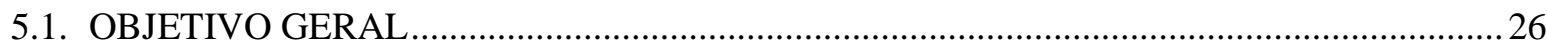

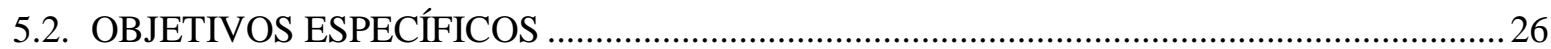

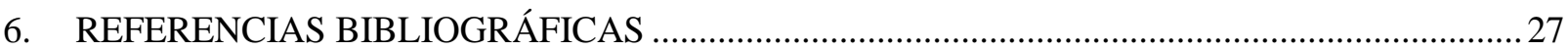

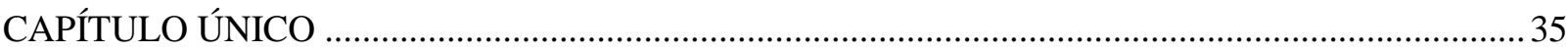

Caracterização agronômica de plantas e teor de carotenoides totais de genótipos de milho em

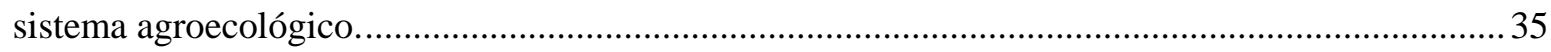

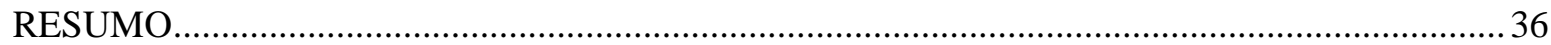

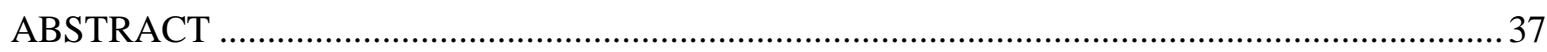

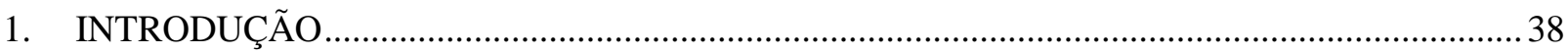

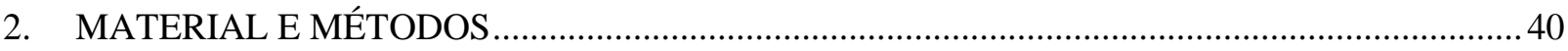

2.1. CARACTERIZAÇÃO DOS GENÓTIPOS UTILIZADOS NO EXPERIMENTO ..................40

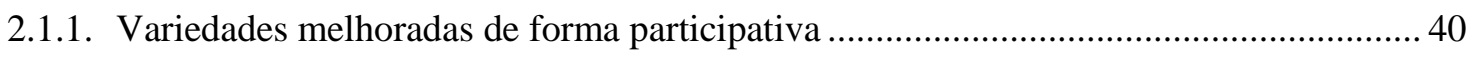

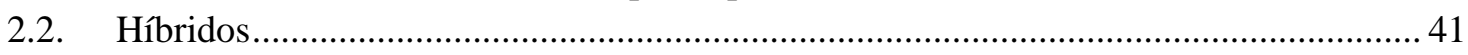

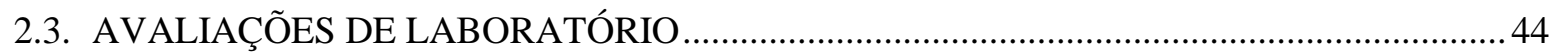

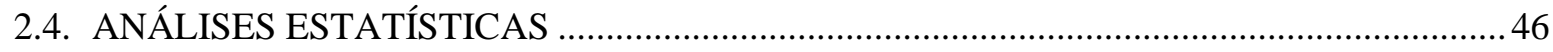

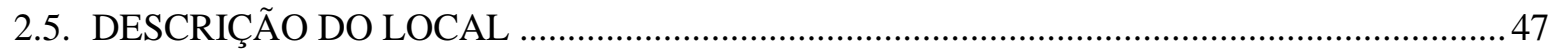

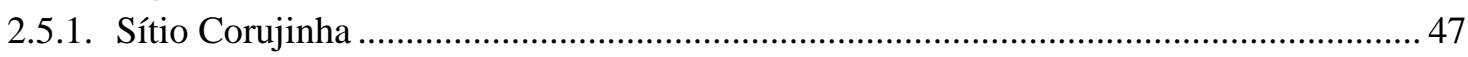

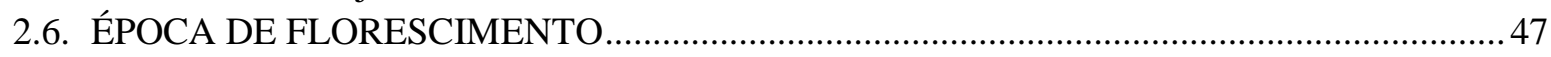

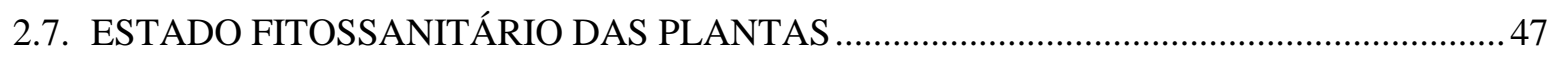

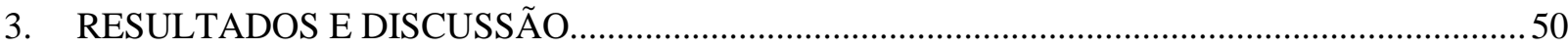

3.1. RESULTADOS DE ANÁLISES LABORATORIAIS DE ADUBO E SOLO E DE

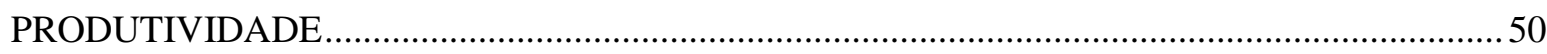

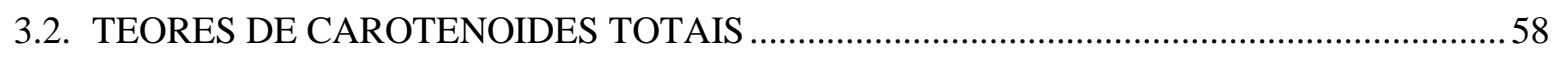

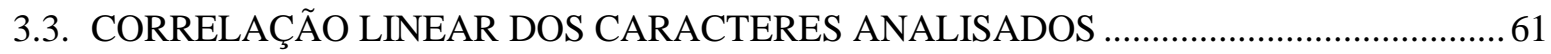

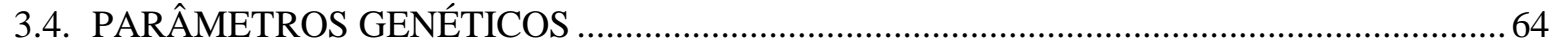

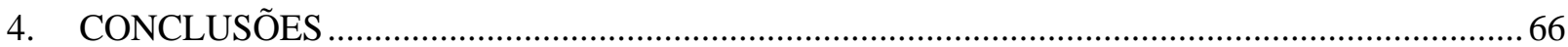

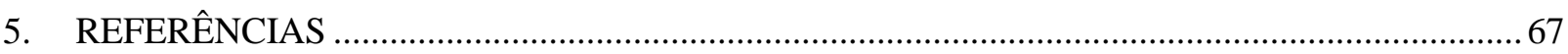

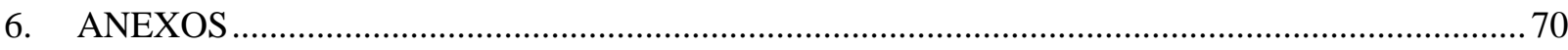




\section{INTRODUÇÃO GERAL}

No início do ano de 2013, o relatório Supply Demand do Departamento de Agricultura dos Estados Unidos (USDA) revelou que o milho foi o cereal mais produzido no mundo e que sua produção mundial atingirá 854 milhões de toneladas nesta safra. Nos últimos cinco anos, sua produção média foi de 778,8 milhões de toneladas. O Brasil sustenta a terceira posição da produção mundial, perdendo para Estados Unidos e China, com produção de 79,9 milhões de toneladas.

O cultivo de milho no Brasil, além de ocupar uma enorme área cultivada, gera empregos no setor agrícola. É importante pela sua utilização direta na alimentação humana e de animais, bem como na indústria para a produção muitos produtos importantes em nosso cotidiano.

Essa cultura gera segurança alimentar, que depende da conservação e do manejo da diversidade genética. A sustentabilidade dos sistemas agrícolas também depende do correto manejo da diversidade genética de espécies e variedades de plantas, que consiste em resgatar, avaliar, selecionar, conservar e caracterizar os recursos genéticos.

Com isso, tem-se reconhecido a contribuição das comunidades de agricultores para a conservação e a valorização da diversidade de recursos genéticos, além de que uma das estratégias definidas com base no Plano de Ação Global para a Segurança Alimentar da FAO refere-se ao uso e a preservação da diversidade genética do milho dentro de pequenas comunidades agrícolas.

Para essa conservação e valorização, o melhoramento de plantas vem sendo desenvolvido e um dos objetivos dos programas de melhoramento genético é o desenvolvimento de cultivares que atendam simultaneamente os produtores e os consumidores como a indústria de transformação e a população que consome os alimentos em natura ou processados. A introdução do milho híbrido se deu por volta da década de 1920 e se constituiu em um dos maiores impulsos da agricultura moderna. Outra modalidade de melhoramento genético do milho é o participativo, englobando uma grande variedade de áreas de pesquisa, baseando-se nos conhecimentos da genética vegetal, da fitopatologia e economia, combinando-os com os da antropologia, sociologia, conhecimento dos agricultores e com os princípios da pesquisa de mercado e desenvolvimento de produtos. 
Em todo o mundo, aproximadamente um terço das crianças com idade pré-escolar têm deficiência de vitamina A (DVA), sendo que $1 \%$ dessas podem adquirir a cegueira noturna através da baixa ingestão. Atualmente, sabe-se que, em função da sua atuação nos olhos, a deficiência dessa vitamina pode provocar quadro de imunodeficiência de origem exclusivamente nutricional.

Fortes evidências indicam que os programas de intervenção nutricional, podem evitar, a cada ano, a morte de até 2,5 milhões de crianças, além de salvar da cegueira nutricional irreversível aproximadamente 500.000 crianças e livrar dessa síndrome de deficiência imunológica nutricional quase 1 bilhão de pessoas (estimativa).

Entretanto, estima-se que os carotenoides provenientes de vegetais possam fornecer aproximadamente $68 \%$ da vitamina A da dieta em termos mundiais, e $82 \%$ nos países desenvolvidos. Uma vantagem dos carotenoides é que somente são convertidos em vitamina A quando houver a necessidade, evitando seu acúmulo.

Com este estudo, podemos esperar com os resultados obtidos que novos produtos e tecnologias possam ser criados, interando-os com as indústrias farmacêuticas, alimentar e cosméticas, possibilitando aos agricultores familiares a permanência do cultivo desse cereal. A apresentação dos resultados foi organizada em um único capítulo, constituído de caracterização agronômica e mensuração do teor de carotenoides totais dos grãos de quatro cultivares de base genética distinta. 


\section{REVISÃO DE LITERATURA}

\subsection{CULTURA DO MILHO}

O milho (Zea mays L.) é uma gramínea pertencente à família Poaceae, tribo Maydeae, diplóide $(2 \mathrm{n}=20)$, alógama, monoica, com protandria. Ocorre perda de vigor quando cruzada com indivíduos aparentados, depressão por endogamia. Sua origem foi descoberta como sendo na América Central e seu cultivo é provavelmente tão antigo quanto os primórdios da agricultura (PATERNIANI; CAMPOS, 2005; MACHADO; MACHADO, 2009). Sua domesticação ocorreu entre 7.000 a 10.000 anos, tornando-se a espécie com maior grau de domesticação (PATERNIANI; CAMPOS, 2005).

É considerada uma das plantas cultivadas mais estudadas, possuindo caracterização genética mais detalhada dentre as espécies cultivadas. Hoje, é uma cultura totalmente dependente da ação do homem, devido sua intensa domesticação (COSTA SANTOS, 2009).

Algumas hipóteses de sua origem foram levantadas, porém, as mais consistentes são aquelas que demonstram que o milho descende do teosinte, que é uma gramínea com vários perfilhos e espigas sem sabugo, que pode cruzar naturalmente com o milho e produzir descendentes férteis (GALINAT, 1995).

Depois do descobrimento da América, a cultura do milho foi levada para a Europa, onde era cultivada em jardins, até que seu valor alimentício tornou-se conhecido (GODOY, 2002). O milho tornou-se uma das plantas cultivadas de maior interesse e extensivos estudos acerca desta cultura permitiram seu cultivo em grande parte dos continentes. Tal fato deve-se à grande plasticidade da planta, decorrente da grande variedade de genótipos existentes (MAGALHÃES et al., 2002). Passou, então, a ser plantada em escala comercial e espalhou-se desde a latitude de $58^{\circ}$ Norte (antiga União Soviética) até $40^{\circ}$ Sul (Argentina) (HALLAUER, 1990; HALLAUER \& MIRANDA FILHO, 1988).

Em condições normais, a plântula de milho emerge entre 5 a 6 dias, em uma temperatura de $25^{\circ} \mathrm{C}$ a $30^{\circ} \mathrm{C}$ (EMCAPA, 1996). No Centro-Oeste brasileiro, durante todo o ciclo da cultura, a temperatura é superior a $15^{\circ} \mathrm{C}$. A temperatura noturna, em alguns locais, é elevada (maior que $24^{\circ} \mathrm{C}$ ), o que afeta o desempenho das plantas, principalmente no período coincidente com aquele entre emborrachamento e grão leitoso, reduzindo a produtividade (EMBRAPA, 2012). 
A semente do milho é uma das que possui maior capacidade de armazenar energia existentes na natureza. Através de uma semente que pesa pouco mais de $0,3 \mathrm{~g}$ irá surgir uma planta, geralmente com mais de $2,0 \mathrm{~m}$ de altura, dentro de um espaço de tempo de aproximadamente nove semanas. Nos meses seguintes essa planta produz cerca de 600 a 1000 sementes, iguais àquelas que a originou (EMBRAPA, 1996).

A produção de milho no Brasil é caracterizada pelo seu plantio em duas épocas distintas: safra de verão (primeira safra) e segunda safra. Na região Centro-Oeste o período da primeira safra ocorre entre setembro e novembro, dependendo da época das chuvas e safrinha refere-se ao milho de sequeiro, plantado, geralmente em fevereiro ou março, quase sempre depois da soja precoce. A quantidade de água consumida durante seu ciclo fica entre 500 e $800 \mathrm{~mm}$ (EMBRAPA, 2012).

Devido à separação das inflorescências masculina e feminina (monóica), o número de sementes produzidas, a facilidade de manipulação, a natureza dos cromossomos e o baixo número de cromossomos $(\mathrm{n}=10)$, a cultura do milho presta-se muito bem a estudos genéticos (BORÉM \& GIÚDICES, 2004). Sua estrutura genética é, portanto, determinada pela forma de acasalamento, com cruzamentos ocorrendo de forma aleatória (NASS et al., 2001). Com a distribuição das inflorescências, separadas uma das outras, torna-se possível realizar autofecundações e cruzamentos controlados, gerando linhagens autofecundadas e a produção de sementes híbridas (BUENO, 2006).

O uso de cultivares de milho adaptadas aos diferentes tipos de solo, clima e sistemas de produção é fundamental para explorar o potencial produtivo. No mundo são utilizados alguns tipos de cultivares de milho: as variedades de polinização aberta e os híbridos. As variedades melhoradas possibilitam obter sementes de baixo custo e podem ser reproduzidas pelo próprio produtor. Essas variedades podem, ainda, apresentar maior estabilidade de produção, sendo inferiores aos híbridos em produtividade em determinados sistemas de produção (EMBRAPA, 2012).

Sangoi et al. (2006) afirmaram que, geralmente, as baixas produtividades de milho decorrem do uso de cultivares e práticas de manejo inadequadas, de condições desfavoráveis de clima e solo em áreas inaptas à cultura e da utilização insuficiente de insumos agrícolas. $\mathrm{O}$ uso de variedades tem demonstrado resultados superiores ao de híbridos, fato esse diretamente associado ao elevado preço das sementes e as condições edafoclimáticas não favoráveis para obtenção do melhor desempenho dos híbridos. 
Rosinha (200) evidenciou que a utilização dos híbridos no Brasil está associada ao tamanho da propriedade e a renda per capita dos produtores, juntamente com sua capacidade de investimento em insumos e tecnologia de produção.

Além disso, Garcia (2007) e Mercadante et al. (1997) relataram que, embora definida, geneticamente, para cada espécie, a composição química da semente pode variar naturalmente com o grau de maturação e pelas condições ambientais durante o período de desenvolvimento.

Ford (2000), relatou que três das quatro cores dos grãos de milho, amarela, vermelha e púrpura, são produzidas por pigmentos sintetizados por um dos dois caminhos metabólicos, os carotenoides (pigmentos amarelados) ou a antocianina (pigmentos vermelhos e púrpuros). A cor branca ocorre por causa da fraca síntese desses pigmentos.

\subsection{DIVERSIDADE GENÉTICA DO MILHO}

A biodiversidade se refere à variedade natural em todos os níveis hierárquicos, desde o nível genético ao de ecossistemas, além de toda a variabilidade existente dentro desses níveis, bem como de suas interrelações ecológicas (GUSSON, 2003).

Pode-se dizer que a diversidade genética é uma medida da biodiversidade, ou seja, mede a variação genética das várias espécies existentes, tanto em populações separadas geograficamente, quanto entre organismos/indivíduos de uma população. O conhecimento relacionado à diversidade genética das espécies traz duas vantagens a um programa de melhoramento. A primeira diz respeito à heterogeneidade genética que limita a vulnerabilidade das espécies às pragas e doenças e a segunda está relacionada ao fornecimento de um amplo suprimento de variação alélica que pode ser usada para criar novas combinações de genes favoráveis (BERTINI, 2003).

Atualmente, a conservação de raças locais (crioulas) tropicais de milho das Américas é feita pelo Centro Internacional de Melhoramento de Milho e Trigo (CIMMYT), situado em Texcoco, no México. Nesse país teve inicio a colheita sistemática, caracterização e utilização de raças locais tropicais em meados dos anos 1940 (NASS et al., 2005). Quando devidamente conservadas, as variedades locais de milho são fontes potenciais de genes na busca por eficiência, tolerância ou resistência em relação aos atuais e futuros estresses bióticos e abióticos (MACHADO et. al., 2011a). 
O estudo da diversidade genética do milho pode ser um importante instrumento de identificação de variedades que apresentam eficiência em sistemas agroecológicos. É importante que as variedades locais e tradicionais, melhoradas geneticamente ou não, continuem nas mãos de agricultores, servindo de banco de sementes e garantindo a segurança alimentar para os mesmos (NUNES, 2006). Machado et al. (2011a) afirmaram que atualmente, a cultura do milho tem aproximadamente 300 raças identificadas e funciona como um reservatório genético, mantendo a capacidade natural de responder às mudanças de clima e aos diferentes estresses sofridos.

Uma das melhores estratégias utilizadas hoje para a conservação das variedades crioulas são os bancos locais de sementes, que tem o controle efetivo das comunidades dos agricultores (MACHADO; MACHADO, 2009).

A agrobiodiversidade apresenta um amplo conceito que inclui uma grande variedade de componentes da diversidade biológica, dos ecossistemas agrícolas até as variedades e genes em espécies de plantas e animais, sendo necessária sua preservação, com o intuito de proteger vidas humanas e promover um contínuo processo de evolução e incrementar a capacidade produtiva dos ecossistemas (NUNES, 2006; MACHADO et al., 2002).

\subsection{MANEJO: OBTENÇÃO DE HÍBRIDOS, MELHORAMENTO PARTICIPATIVO E USO (CAMPO E NUTRICIONAL)}

Borém (1999) afirmou que as cultivares de milho são classificadas quanto à metodologia de obtenção em dois tipos principais: híbridos e variedades de polinização aberta.

\subsubsection{Obtenção do milho híbrido}

O milho híbrido começou a ser introduzido na agricultura moderna por volta de 1920 , sendo que os primeiros híbridos comerciais apareceram na década de 30 e foram substituindo gradativamente as variedades de polinização aberta. No final da década de 30, os híbridos de milho já representavam $75 \%$ da área cultivada nos Estados Unidos, alcançando o índice de 95\% na década de 60 (BUENO, 2006). O termo "híbrido" se refere a qualquer planta produzida através de parentais geneticamente diferentes, ou seja, é o cruzamento entre 
linhagens oriundas de populações distintas geneticamente (CHÁVES CABRERA, 2001; NASS et al., 2001).

Allard (1971) relatou que o termo "milho híbrido" pode ser definido como a primeira geração proveniente do cruzamento entre variedades de polinização aberta, linhagens endogâmicas ou outras populações geneticamente divergentes. Esses cruzamentos são considerados as unidades fundamentais para o desenvolvimento de programas de produção de híbridos.

Estudos iniciais acerca da hibridação em milho foram conduzidos por Shull (1909) e East (1909), sendo considerados por alguns autores os pais do milho híbrido. Fizeram estudos diferentes, chegando a uma mesma conclusão: estabeleceram o sistema endogamiahibridação. Verificaram que extraindo linhagens mediante autofecundações sucessivas e cruzando essas linhagens endogâmicas, era possível selecionar os melhores genótipos e reproduzí-los indefinidamente.

Desde esta descoberta, o método do milho híbrido vem sendo amplamente utilizado, tanto em sistemas agroecológicos quanto em sistemas convencionais de plantio, consistindo na obtenção das linhagens autofecundadas (linhas puras) e sua utilização em cruzamentos entre si, para a produção de sementes híbridas (híbrido simples - HS). De acordo com Vencovsky (1987) o híbrido de milho ideal seria aquele oriundo de duas linhagens em que todos os seus locos com efeitos não aditivos fossem heterozigotos.

QUADRO 1. Tipos de híbridos de milho e cruzamentos respectivos (HALLAUER, 1990; HALLAUER \& MIRANDA FILHO, 1988).

\begin{tabular}{cc}
\hline Tipos de híbridos & Cruzamentos envolvidos \\
\hline Top-cross & Linhagem x Cultivar \\
Híbrido simples & Linhagem A x Linhagem B \\
Híbrido simples modificado & $\left(\mathrm{A} \times \mathrm{A}^{\prime}\right) \times \mathrm{B}$ ou $\left(\mathrm{A} \times \mathrm{A}^{\prime}\right) \times\left(\mathrm{B} \times \mathrm{B}^{\prime}\right)$ \\
Híbrido triplo & $(\mathrm{A} \times \mathrm{B}) \times \mathrm{C}$ \\
Híbrido duplo & $(\mathrm{A} \times \mathrm{B}) \times(\mathrm{C} \times \mathrm{D})$ \\
Híbrido múltiplo & $(\mathrm{AxB}) \times(\mathrm{CxD}) \times(\mathrm{ExF}) \times(\mathrm{GxH})$ \\
Híbrido intervarietal & Variedade A x Variedade B
\end{tabular}


Os programas de melhoramento de milho, privados ou públicos, têm como objetivo o incremento da produtividade pelo aumento da tolerância aos estresses bióticos (pragas e doenças), resistência de plantas ao acamamento e melhor qualidade dos grãos, além de resistência às podridões de colmo e espiga. Os estresses abióticos também são considerados, como os fatores relacionados à fertilidade do solo e à disponibilidade hídrica. Alguns programas visam outras características além destas, como a obtenção de tipos especiais de milho com alta qualidade nutricional (SOUZA JR., 2001). São apresentados os diferentes tipos de híbridos em milho no Quadro 1.

Existem outros tipos de híbridos, os modificados, que podem ser subdivididos em híbridos simples modificado e triplos modificados. Os simples podem ainda ser divididos em três tipos: Na primeira, as duas linhagens que formam o híbrido simples são linhagens aparentadas. Na segunda, uma linhagem modificada oriunda da população 1 é cruzada com uma linhagem vinda da população 2 e na terceira, uma linhagem pura da população 1 é cruzada com uma linhagem modificada da população 2. Existem dois tipos de híbridos triplos modificados, tipo I, onde a linhagem modificada oriunda da população 2 é cruzada com o híbrido simples da população 1, e os do tipo II, a linhagem modificada oriunda da população 1 é cruzada com um híbrido simples da população 2 (HALLAUER, 1990; SOUZA JR., 1997).

A formação de híbridos é um método de melhoramento de plantas que procura tirar grande proveito dos efeitos da heterose. A hibridação no sentido mais amplo tem-se constituído uma ferramenta de grande importância no melhoramento de grande parte das espécies cultivadas, pois sua prática permite tanto a exploração do vigor de híbrido na geração $\mathrm{F}_{1}$ como também permite o aparecimento de variabilidade genética em populações (NASS et al., 2001; BUENO, 2006).

A expressão variedade híbrida designa as populações $F_{1}$ plantadas comercialmente, resultantes de cruzamento entre variedades de polinização aberta, linhagens autofecundadas ou outras populações geneticamente não semelhantes (ALARD, 1971). Geneticamente o potencial produtivo dos híbridos é maior que o das variedades, pois, quando esses últimos são submetidos à endogamia, apresentam uma redução geral do vigor e da produtividade, devido à carga genética e, também, pela redução na quantidade dos locos em heterozigoze em que não há alelos recessivos deletérios ou letais (NASS et al., 2001; PATERNIANI, 2001), fenômeno denominado de "depressão endogâmica".

Nos programas de melhoramento de milho, o fenômeno da heterose é de grande importância na identificação de populações geneticamente divergentes, como base para o 
desenvolvimento de linhagens a serem utilizadas em cruzamentos híbridos e com o propósito de capturar o efeito gênico não aditivo que promove a dominância (HALLAUER, 1990).

Costa (2006) relatou que o termo heterose é utilizado para descrever a manifestação da superioridade de um caráter quantitativo em combinações híbridas de plantas e de animais.

Shull (1909 apud PATERNIANI, 2001) definiu como heterose o vigor de híbrido manifestado em gerações heterozigotas derivadas de cruzamento entre indivíduos endogâmicos e geneticamente divergentes. Foram alcançados altos níveis de produtividade, representando uma das maiores contribuições práticas da genética à agricultura mundial (PATERNIANI, 2001).

Além disso, Hallauer (1990) mostrou estudos que revelam que cruzamentos entre genótipos geneticamente divergentes, proporcionam grande vigor em relação àqueles cruzamentos entre indivíduos semelhantes geneticamente.

Paterniani; Campos (2005), relataram que os programas de melhoramento de milho devem envolver, pelo menos, quatro etapas: a escolha de populações, a obtenção de linhagens, a avaliação da capacidade de combinação entre elas e testes extensivos das combinações híbridas obtidas.

Para a escolha das populações, os materiais devem ser provindos de populações diferentes, explorando-se a heterose existente. Com isso, criam-se híbridos interpopulacionais, sua produção final se dá com materiais oriundos de diferentes populações (NASS et al., 2001), e, nessas, devem se concentrar os alelos favoráveis para as características de interesse, permitindo a extração de linhagens superiores (HALLAUER, 1990, PATERNIANI \& CAMPOS, 2005).

A segunda fase é a obtenção das linhas puras, ou seja, sucessivas autofecundações são realizadas para que a homozigoze total seja praticamente atingida. Nesta fase, a obtenção de linhagens e o seu comportamento em combinações híbridas (capacidade de combinação), bem como o potencial "per se" é um dos objetivos básicos num programa de melhoramento genético, devido ao seu emprego na formação de híbridos comerciais (LEMOS et al., 2002).

Os órgãos masculinos e femininos são protegidos com sacos de papel, e no momento certo, é realizada a autopolinização das plantas já selecionadas. A cada geração de autofecundação, o nível de heterozigoze é reduzido à metade. Conduto, na sétima geração, considera-se que as plantas já atingiram a homozigoze, estando as linhagens com os caracteres fixados e podem ser facilmente diferenciadas das outras, através de testes, além de que as variações entre plantas dentro de cada linhagem são praticamente imperceptíveis. Esse processo é utilizado para melhoramento de espécies autógamas, sendo denominado de 
genealógico e é considerado o mais rápido (BUENO, 2006; HALLAUER, 1990; NASS et al., 2001). Nass et. al. (2001) relataram, ainda, que além da performance dos cruzamentos, as populações devem ser avaliadas quanto à depressão por endogamia e selecionadas aquelas menos sensíveis à endogamia.

Para o melhoramento das linhagens deve-se evitar a redução da base genética do material empregado, pois poderá determinar redução da produtividade do híbrido originado. Os retrocruzamentos são feitos quando uma linhagem elite, isto é, aquela que é utilizada para a produção de híbridos, possui algumas características desfavoráveis que se encontram em linhagens consideradas não elites, denominadas de doadoras. Com isso a linhagem elite é cruzada com a doadora e, depois, diversos retrocruzamentos são feitos para a linhagem elite, acompanhado de intensa seleção para incorporar os caracteres desejados e para a recuperação da performance da linhagem elite. $\mathrm{O}$ número de retrocruzamentos depende da divergência genética das linhagens parentais e quanto mais diferentes em performances forem essas linhagens maior deve ser o número de retrocruzamentos e vice-versa (BUENO, 2006; NASS et al., 2001).

Relatou Bueno (2006) que, para o melhoramento de linhagens um dos métodos mais utilizados é o retrocruzamento, sendo o cruzamento do $F_{1}$ com qualquer um de seus progenitores. Este método exige a escolha certa do progenitor não-recorrente; procura-se trabalhar com um tamanho adequado da população, para que, na segregação, consigam-se os tipos desejados. Pela sua própria natureza, é um método eficiente para transferir um ou mais caracteres monogênicos. O progenitor recorrente é, geralmente, uma linhagem com boas características agronômicas, mas com alguns defeitos que se desejam eliminar. O progenitor não-recorrente não deverá ser portador desses defeitos. A cada retrocruzamento os genótipos tornam-se mais homozigotos e a constituição genotípica das progênies aproxima-se gradativamente daquela do progenitor recorrente.

Ramalho et al (1993) mostraram que a capacidade de combinação (Ci) pode ser usada para a escolha de genitores e híbridos potencialmente superiores. Os valores genéticos dos genitores e das combinações híbridas presentes em um dialelo são efetuados sobre a natureza dos efeitos gênicos envolvidos na determinação da característica sob análise, revelando informações importantes para o planejamento de programas de melhoramento quanto à estratégia de seleção e escolha dos seus métodos.

Miranda Filho e Gorgulho (2001), com base no trabalho de Sprague e Tatum (1942), mencionaram que o termo Capacidade Geral de Combinação (CGC) refere-se ao comportamento médio de um genitor em cruzamento com os demais do conjunto, 
principalmente devido ao efeitos aditivos dos genes e definem que a Capacidade Específica de Combinação (CEC) é interpretada como um efeito na expressão do híbrido que é adicional aos efeitos de CGC dos pais, podendo ser positivo ou negativo. Ou seja, a CEC resulta da interação dos efeitos de CGC dos pais e pode melhorar ou piorar a expressão do híbrido em relação ao efeito esperado com base somente na CGC. Ferreira et al. (2004) afirmam que a CGC é influenciada também pelos efeitos de dominância.

A Capacidade de Combinação de linhagens ou genótipos reflete seu valor genético relativo intrínseco. Linhagens com maior estimativa de Ci deverão resultar em cruzamentos superiores devido ao seu valor genético (NASS et al., 2001).

\subsubsection{Melhoramento Participativo}

Almenkinders e Elings (2002) mostraram que quando se considera a ineficiência da agricultura de mercado em promover o desenvolvimento rural sustentável em ambientes adversos e, principalmente, em conservar a biodiversidade ainda existente nas comunidades rurais, chegou-se a conclusão que a participação dos agricultores nos programas de melhoramento genético era essencial e que sem esta participação os programas de melhoramento estabelecidos, geralmente em propriedades de agricultura de subsistência, seriam, na maioria dos casos, condenados ao fracasso.

Um problema que atinge todo o mundo na atualidade é a fome, principalmente nos países que estão se desenvolvendo. Vários fatores estão relacionados com este fator, como o aumento demográfico, a questão da terra improdutiva e ociosa, a política agrícola, entre outros. Com isso, o correto manejo dos recursos vegetais, incluindo o Melhoramento Participativo de Culturas (MPC), desempenha um papel relevante em comunidades de agricultura familiar, podendo contribuir para a construção de um ambiente agrícola sustentável (MACHADO, 2002; MACHADO, 2006).

Segundo Machado e Machado (2007) o melhoramento participativo de cultivos pode ser considerado um recorte da agrobiodiversidade em que diferentes ações de manejo estão envolvidas, como por exemplo, métodos de seleção, resgate, avaliação, caracterização, seleção e conservação dos recursos genéticos, visando à caracterização e o desenvolvimento de variedades adaptadas a esses ambientes que tem uma lógica própria no estabelecimento de espécies vinculadas a um agroecossistema funcional. 
Esse tipo de melhoramento começou a ser delineado nos anos 80 como alternativa e complemento ao melhoramento formal dado que este havia gerado poucos benefícios do ponto de vista agroecológico e socioeconômico para os agricultores, enfrentando condições agroecológicas e socioeconômicas marginais (MACHADO, 2011b; ALMEKINDERS; ELINGS 2002). Junto ao MPC estão a inclusão sistemática dos conhecimentos, habilidades, experiências, práticas e saberes dos agricultores (MACHADO; MACHADO, 2009, BOEF et al., 2007).

Segundo Rocha (2008) esta técnica consiste na seleção de cultivares com a participação efetiva do agricultor. É considerada a técnica de melhoramento mais eficaz para os pequenos produtores que se dedicam às culturas de subsistência, os quais dispõem de pequenas áreas, adotam nenhum ou baixo nível de tecnologia e, além disso, têm difícil acesso às cultivares melhoradas.

Londres (2009) diz que o objetivo do melhoramento participativo é realizar um processo coletivo onde se valoriza o conhecimento do agricultor no manejo e qualidade do produto, aliado ao conhecimento do melhorista nas técnicas de seleção. Outro fator valorizado é a conservação da agrobiodiversidade ou do germoplasma local de plantas cultivadas há várias gerações pelos agricultores de uma determinada comunidade, além de aumentar a frequência dos genes favoráveis (MACHADO; MACHADO, 2009).

Boef et al. (2007) relataram que o melhoramento genético participativo leva em consideração aspectos socioeconômicos, culturais e ecológicos da realidade do agricultor familiar. Considera o valor da adaptação dos cultivos ao manejo do agricultor em relação aos fatores bióticos e abióticos e valoriza os critérios de seleção usados pelo próprio agricultor.

Para Machado e Machado (2009), além dos aspectos citados acima, devem ser considerados os aspectos ambientais. A integração de diferentes disciplinas pode auxiliar na construção de um novo paradigma juntamente com o saber popular e a pesquisa-ação. Relataram, ainda, que o MPC possui múltiplos objetivos, sendo mais amplos do que os do melhoramento convencional. Tem por metas o ganho de produtividade, a conservação e promoção do aumento da biodiversidade, a obtenção e uso de germoplasma de adaptação local, a seleção dentro de populações, a avaliação experimental de variedades (também denominada seleção participativa de variedades), o lançamento e divulgação de novas variedades, a diversificação do sistema produtivo e produção de sementes.

Guadagnin e Guadagnin (2009) relataram que o melhoramento participativo de variedades locais de milho proporciona a reformulação das estratégias convencionais de 
melhoramento. Este processo promove a pesquisa com a participação dos agricultores, extensionistas, pesquisadores e professores a fim de assegurar que a tomada de decisão conjunta responda as necessidades das famílias de agricultores, através da organização social para a construção de novos conhecimentos.

O melhoramento genético de plantas formal diferencia-se do participativo em alguns aspectos. No primeiro, busca-se um incremento nos genes de efeito aditivo e, consequentemente, uma maior herdabilidade no sentido restrito, menor interação dos genótipos com o ambiente e maior estabilidade na produção (MACHADO et al., 2011b). Nunes (2006) relatou que a variedade melhorada de forma participativa difere da variedade melhorada convencional no fato de que, durante o desenvolvimento da primeira, houve a efetiva participação dos agricultores durante todo o processo de melhoramento, além da participação do melhorista.

Um dos problemas do melhoramento genético de plantas formal são as áreas marginais, onde as dificuldades com os estresses são constantes e, normalmente, os programas de melhoramento convencionais não atendem essas áreas, exigindo mudanças estratégicas dentro dos componentes genéticos para a seleção nesses ambientes (MACHADO et al., 2011a).

Ainda, segundo os autores citados anteriormente, a estratégia utilizada para contornar esse problema é o uso do melhoramento participativo, tornado-se um importante processo para se conseguir genótipos superiores para esses ambientes. A relação entre genótipos e ambientes ganha outra conotação, em que, na maioria das vezes buscam-se interações a ambientes específicos.

Boef et al. (2007) relataram que os impactos dos programas de melhoramento genético de plantas podem ser obtidos mais rapidamente e com maior eficiência em sistemas agroecológicos quando estratégias participativas são aplicadas nas várias etapas do processo.

O correto manejo da diversidade genética tem o melhoramento participativo como um componente que permite resgatar, avaliar, caracterizar, selecionar e conservar os recursos genéticos de variedades locais de milho com a inclusão sistemática dos conhecimentos, habilidades, experiências, práticas e preferências dos agricultores através de ações de pesquisa, extensão e aprendizagem participativa (GUADAGNIN; GUADAGNIN, 2009), além dos conhecimentos da genética convencional, fisiologia e economia, combinado-os com os da antropologia, sociologia, conhecimento dos produtores e com os princípios de desenvolvimento de produtos (SOLERI; SMITH, 2002). 
Nunes (2006) diz que o MPC deve ser uma regra e não uma exceção. Além de tornar os agricultores coautores do processo, a economia de tempo e de dinheiro é grande, visto que, durante o processo de melhoramento, os agricultores vão adotando aquilo que acreditam ser bom para eles e eliminando o que lhes parece não ser interessante. As comunidades de agricultores familiares devem participar de todas as etapas do processo de melhoramento, a fim de garantir a sua autonomia e a sua soberania alimentar (MACHADO; MACHADO, 2009).

Variedades locais ou crioulas foram e ainda são a principal fonte de germoplasma para a maioria dos agricultores familiares, bem como a matéria-prima de alguns programas de melhoramento convencional e de todos os programas de MPC (BOEF et al., 2007).

Araújo e Nass (2002) afirmaram que a conservação das variedades de polinização aberta é importante, pois as mesmas constituem fonte de variabilidade genética que pode ser explorada na busca de genes que confiram tolerância a estresses abióticos ou resistência a doenças. As variedades de polinização aberta (VPA) apresentam como características favoráveis a maior estabilidade de produção, o menor custo inicial da semente e a possibilidade de reutilizá-la por vários anos agrícolas (BISOGNIN et al., 1997). Além disso, para Balbinot Jr. et al. (2005), as VPA constituem-se em alternativa ao uso de híbridos, principalmente por agricultores que não possuem capital disponível para a aquisição de sementes híbridas.

Essas práticas contribuem para a construção de um ambiente agrícola sustentável, com a elevação de renda e agregação de valores ambientais e sociais, criando as bases para a soberania alimentar das comunidades, que passam a ter autonomia sobre a produção das sementes (MACHADO; MACHADO, 2009).

Contudo, para Machado e Machado (2009) no melhoramento participativo há três elementos que devem ser considerados como fundamentais para que a proposta tenha sucesso: incrementar a diversidade de variedades locais; estabelecer mecanismos de conservação local e empoderamento dos agricultores (Figura 1). 


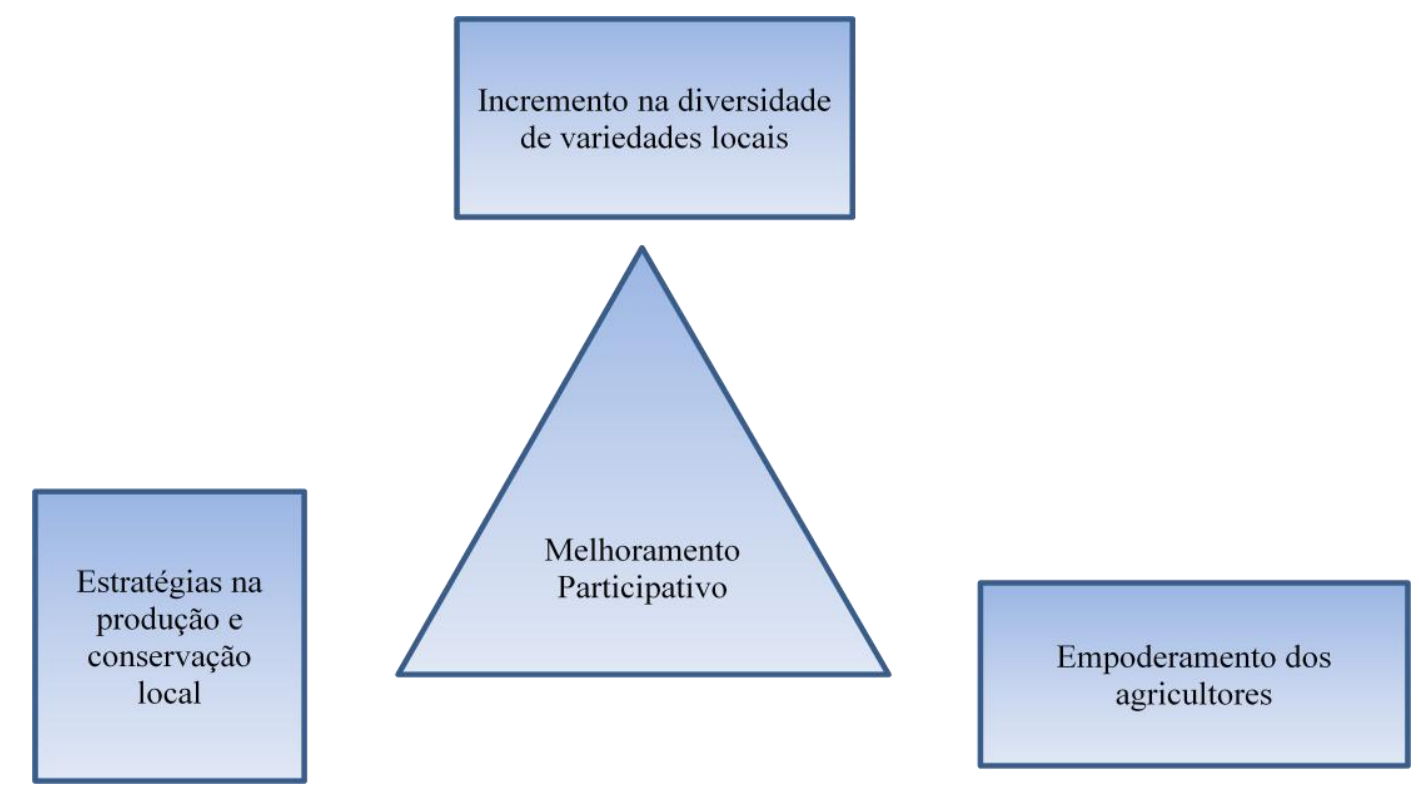

FIGURA 1. Três componentes básicos do melhoramento participativo (MACHADO; MACHADO, 2009).

\subsubsection{A utilização do milho}

Esta cultura é caracterizada por suas diversas formas de utilização, indo desde a alimentação humana e animal até a indústria de alta tecnologia. A maior parte do consumo do milho é em grãos para a alimentação animal (DUARTE, 2000). Atualmente, somente cerca de $5 \%$ da produção brasileira se destina ao consumo humano e, mesmo assim, de maneira indireta na composição de outros produtos. Isto se deve principalmente à falta de informação sobre o milho e à ausência de uma maior divulgação de suas qualidades nutricionais, bem como aos hábitos alimentares da população brasileira, que privilegia outros grãos, como o arroz e o feijão.

Para Machado e Machado (2007), dois aspectos fundamentais da cultura do milho devem ser levados em consideração: sua grande diversidade genética, tornando o cultivo do milho possível em distintas áreas, e o seu uso diverso para a alimentação humana e animal além do uso na indústria agrícola. 
QUADRO 2. Os múltiplos usos do milho (planta, espiga e grão). Destinação e forma/produto final.

\begin{tabular}{|c|c|}
\hline Uso Animal Direto & Silagem; Rolão; Grãos (inteiro/desintegrado) para aves, suínos e bovinos. \\
\hline $\begin{array}{l}\text { Uso Humano Direto de Preparo } \\
\text { Caseiro }\end{array}$ & $\begin{array}{l}\text { Espiga assada ou cozida; Pamonha; Curau; Pipoca; Pães; Bolos; Broas; } \\
\text { Cuscuz; Polenta; Angus; Sopas; Farofa. }\end{array}$ \\
\hline Indústria de Rações & $\begin{array}{l}\text { Rações para aves (corte e postura); outras aves; Suínos; Bovinos (corte e } \\
\text { leite); Outros mamíferos. }\end{array}$ \\
\hline $\begin{array}{l}\text { Indústria de Alimentos } \\
\text { Produtos Finais }\end{array}$ & $\begin{array}{l}\text { Amidos; Fubás; Farinhas comuns; Farinha pré-cozidas; Flocadas; } \\
\text { Canjicas; Óleo; Creme; Pipocas; Glicose; Dextrose. }\end{array}$ \\
\hline Intermediários & Canjicas; Sêmola; Semolina; Moído; Granulado; Farelo de germe. \\
\hline Xarope de Glucose & $\begin{array}{l}\text { Balas duras; Balas mastigáveis; Goma de mascar; Doces em pasta; } \\
\text { salsichas; salames; Mortadelas; Hambúrgueres; Outras carnes } \\
\text { processadas; Frutas cristalizadas; Compotas; Biscoitos; Xaropes; Sorvetes; } \\
\text { Para polimento de arroz. }\end{array}$ \\
\hline $\begin{array}{l}\text { Xarope de Glucose com alto teor } \\
\text { de maltose }\end{array}$ & Cervejas \\
\hline Corantes Caramelo & Refrigerantes; Cervejas; Bebidas alcoólicas; Molhos. \\
\hline Maltodextrinas & $\begin{array}{l}\text { Aromas e essências; Sopas desidratadas; Pós para sorvetes; Complexos } \\
\text { vitamínicos; Produtos achocolatados. }\end{array}$ \\
\hline Amidos Alimentícios & $\begin{array}{l}\text { Biscoitos; Melhoradores de farinhas; Pães; Pós para pudins; Fermento em } \\
\text { pó; Macarrão; Produtos farmacêuticos; Balas de goma. }\end{array}$ \\
\hline Amidos Industriais & $\begin{array}{l}\text { Para papel; Papelão ondulado; Adesivos; Fitas Gomadas; Briquetes de } \\
\text { carvão; Engomagens de tecidos; Beneficiamento de minérios. }\end{array}$ \\
\hline Dextrinas & $\begin{array}{l}\text { Adesivos; Tubos e tubetes; Barricas de fibra; lixas; Abrasivos; Sacos de } \\
\text { papel; multifolhados; Estampagem de tecidos; Cartonagem; } \\
\text { Beneficiamento de minérios. }\end{array}$ \\
\hline Pré-Gelatinizados & Fundição de peças de metal. \\
\hline Adesivos & $\begin{array}{l}\text { Rotulagem de garrafas e de latas; Sacos; Tubos e tubetes; Fechamento de } \\
\text { caixas de papelão; Colagem de papel; madeira e tecidos. }\end{array}$ \\
\hline Ingredientes Proteicos & Rações para bovinos; suínos; aves e cães. \\
\hline
\end{tabular}

Fonte: Jornal Agroceres (1994) 
Em estudos, Souza e Braga (2004) relataram que a importância do milho para a produção animal pode ser verificada pelo emprego de $80 \%$ de todo o milho produzido no país ser consumido na forma de ração. Este consumo serve como energia para a produção de proteínas na forma de leite, ovos e carne (NUNES, 2006), principalmente na fabricação de rações para aves e suínos, sendo esses os maiores consumidores.

A utilização para o consumo animal pode ser dividida em três situações: na produção de silagem, sendo utilizado para alimentação de animais em produção de leite e de animais confinado para engorda no período de inverno; na industrialização do grão de milho em ração; e para o emprego do grão em mistura com concentrados protéicos, para a alimentação de suínos e de aves (GARCIA et al., 2006).

Combinado com outros ingredientes, o milho pode ajustar a formulação de rações específicas para a dieta balanceada de acordo com o tipo e a destinação dos animais, a exemplo de suínos em geral, leitões, matrizes, aves poedeiras ou de corte, gado de leite ou de corte. Além disso, o alimento pode ser processado e utilizado por dois principais processos (seco e úmido) para a produção de produtos como: farelo de milho moído, farelo de gérmen de milho peletizado, farinhas pré-gelatinizadas, milho em grãos, fubá grosso, glúten de milho, farelo de glúten de milho e farelo de milho (CIB, 2006).

O uso desse cereal para a fabricação do etanol avança no Brasil. A prática ainda é pequena e restrita ao Mato Grosso, mas há pelo menos nove projetos pelo país para transformar o grão em combustível. O milho combina muito bem com a entressafra da cana, reduzindo o custo fixo da usina. Aproximadamente cada tonelada de milho gera 370 litros de etanol, 200 quilos de farelo protéico destinados à ração, e 20 litros de óleo bruto de milho (com uso industrial e também de alimentação animal). Ou seja, complementam a produção do etanol, dando viabilidade à atividade (BATISTA, 2013).

Garcia et al. (2006) relataram que mesmo para o consumo humano, o milho necessita de certas transformações. À exceção é quando os grãos estão em estado leitoso, ou "verde", pois os secos não podem ser consumidos diretamente pelos seres humanos. O milho pode ser industrializado através dos processos de moagem úmida e seca. Este último é o mais utilizado no Brasil. Deste processo resultam subprodutos como a farinha de milho, o fubá, a quirera, farelos, óleo e farinha integral desengordurada, envolvendo escalas menores de produção e menor investimento industrial. O processamento industrial do milho rende, em média, $5 \%$ do seu peso na forma de óleo. Através do processo de moagem úmida o principal subproduto 
obtido é o amido, cujo nome do produto foi praticamente substituído pela designação comercial de Maizena®.

Segundo Menegaldo (2011) o milho é a matéria-prima principal de vários pratos da culinária típica brasileira como canjica, cuscuz, polenta, angu, mingaus, pamonhas, cremes, entre outros como bolos, pipoca ou simplesmente milho cozido ou assado, sendo um alimento com alto potencial energético devido ao seu importante teor de amido. Apresenta, ainda, carotenoides ligados à prevenção de doenças degenerativas da visão, como a zeaxantina e a luteina, carotenoides presentes em maior concentração na região macular da retina do olho humano, daí sua importância também na prevenção da cegueira.

As cultivares de milho destinadas a programas de melhoramento genético com concentrações superiores de pró-vitamina A podem ajudar nos programas de combate à deficiência de vitamina A, principal causa da cegueira em crianças no Brasil, além daquelas participantes do programa de biofortificação em ferro e zinco, que ajudam a diminuir as carências nutricionais. A variedade de milho de alta qualidade proteica (QPM) BR 473, é um sintético de ciclo precoce, de grãos amarelos semiduros, com elevados teores de proteínas e composição mais privilegiada de aminoácidos essenciais, cerca de 50\% mais de lisina e triptofano. Podem ser utilizados na confecção de alimentos mais nutritivos e rações mais baratas, com aparência e sabor similares aos de milho comum. Essa vantagem pode ser traduzida em maiores ganhos de peso quando o milho é a principal fonte de energia e proteína ou na redução dos custos de produção de carne de suínos e aves (PACHECO et al., 2000; MENEGALDO, 2011). Esta cultivar é um sintético formado por seis linhagens-elites progenitoras de três híbridos simples que, por sua vez, formaram três híbridos duplos que foram competitivos com o BR 201 (GUIMARÃES et al., 2004).

As fibras resultantes do processamento do milho por meio da moagem também possuem efeitos benéficos à saúde humana, já que influenciam no perfil das lipoproteínas conjunto de proteínas e lipídeos que ajudam o transporte da gordura pelo plasma - e nos níveis de colesterol sanguíneo. Esses efeitos têm sido atribuídos ao importante papel exercido pela fibra na redução do tempo de trânsito intestinal e pelos benefícios na própria flora intestinal, quanto à influência direta no metabolismo de ácidos biliares e na absorção de colesterol, triglicérides e outros lipídeos séricos no intestino (MENEGALDO, 2011). Além desses produtos derivados da moagem, uma série de novos produtos industriais foram acrescentados dentre os destinados ao consumo humano. Os de maior importância são o amido, derivado da moagem úmida, e o óleo de milho. Devido à complexidade de seu 
processamento, e à necessidade de capital envolvido, esses produtos são oriundos de empresas de grande porte (GARCIA et al., 2006).

Segundo CIB (2006) o milho é muito energético. Traz em sua composição vitaminas A e do complexo B, além de proteínas, gorduras, grandes quantidades de açúcares, celulose, carboidratos, cálcio, ferro, fósforo e amido, e também é rico em fibras. Cada 100 gramas do alimento tem cerca de $360 \mathrm{Kcal}$, sendo $70 \%$ de glicídios, $10 \%$ de protídeos e 4,5\% de lipídeos.

Além disso, Nunes (2006) mostrou que o milho tem uma importância fundamental para o sustento das famílias dos agricultores familiares. Serve como alimento e é também uma fonte de renda, pois o excedente da produção pode ser comercializado.

\subsection{CAROTENOIDES}

Nas plantas, os carotenoides participam da fotossíntese e absorvem energia luminosa, transferindo-a para os centros de reação da clorofila, além de protegerem o aparato celular fotossintético contra danos foto-oxidativos (WALTON; BROWN, 1999; BARTLEY; SCOINIK, 1995 citados por KUHNEN et al., 2011).

Além disso, aproximadamente 50 carotenoides têm relevância na nutrição humana e ao menos 40 atuam como precursores na síntese de compostos retinoides. Outras funções também são exercidas pelos carotenoides, como proteção contra danos causados pela radiação solar, feita pelas xantofilas, luteína e zeaxantina, as quais se concentram nas áreas expostas do organismo humano (GRUNE et al., 2005).

Os carotenoides são pigmentos lipossolúveis naturais com variação de cor entre o amarelo e o vermelho escuro, sendo essa variação, um quesito de valor na motivação do consumidor de carnes, ovos e o mercado de cosméticos, além de achar-se popularizado o conceito de que os carotenoides são efetivamente saudáveis (FONTANA et al., 2000). Estão presentes em diversas frutas e vegetais. Nas plantas superiores, estão localizados em organelas subcelulares (cloroplastos e cromoplastos). Nos cloroplastos estão juntos às proteínas, sendo, normalmente, mascarados pela presença de outros pigmentos clorofílicos dominantes, atuando como pigmentos fotoprotetores na fotossíntese e como estabilizadores de membranas (KURZ; CARLE; SCHIEBER, 2008). 
Nos tecidos de plantas comestíveis, existe grande variedade de carotenoides. Os mais comuns são: tomates (licopeno), cenouras ( $\alpha$ e $\beta$-caroteno), milho (luteína e zeaxantina), pimentas vermelhas (capsantina), urucum (bixina) e batata doce ( $\beta$-caroteno). Estudos recentes mostram que a função antioxidante dos carotenoides desempenha um papel importante na redução do risco de câncer, catarata, ateriosclerose e no processo de envelhecimento (DAMODARAN, PARKIN; FENNEMA, 2008).

Como precursores da vitamina $\mathrm{A}$, alguns desses pigmentos são responsáveis pela prevenção da hipovitaminose A (RIOS et al., 2008). Nos grãos do milho estão presentes as xantofilas, que são as luiteínas, $\beta$-criptoxantina e a zeaxantina, que perfazem aproximadamente $90 \%$ do total e os carotenos, $\alpha$ e $\beta$-caroteno, que são encontrados em pequena concentração. (JANICK-BUCKNER et al., 1999; RIOS et al., 2008).

Oliveira Júnior et al. (2006) também afirmaram que as xantofilas são prevalentes no milho, sendo que o enlatado, as farinhas e os cereais matinais a base de milho, são boas fontes de zeaxantina. Porém, quando se preparam os produtos, como a pamonha, o curau, a polenta frita e cozida, há uma diminuição considerável nos teores de carotenoides após processamento. Puderam afirmar também que existe diferença significativa no teor de xantofilas entre diferentes marcas de milho enlatado, farinhas e cereais matinais à base de milho.

Volpi et al. (2010) concluíram que o processamento do milho realizado via moagem a seco dos grãos afeta diretamente a retenção de carotenoides em canjica, fubá e creme de milho, revelando perdas expressivas. O creme de milho quando comparado aos demais derivados é o produto que apresenta os menores índices de retenção para carotenoides totais, evidenciando a influência do tipo e condições de processamento, bem como das características que são inerentes a cada matriz alimentícia.

Alguns estudos epidemiológicos e clínicos mostraram que a baixa ingestão ou baixa concentração desses carotenoides no plasma está associada com a degeneração macular relacionada à idade (DMI) e que os benefícios dos carotenoides em humanos não são só para os olhos. A conclusão de estudos mostra que eles podem manter a saúde do coração, reduzindo os riscos de doenças cardiovasculares e protegem a pele dos danos causados por radiação ultra violeta (SANTOCONO et al., 2007; MARINOVA; RIBAVORA, 2007 citados por KUHNEN et al., 2011).

Lemos et al. (2006) relataram que alguns estudos associam a alta ingestão de carotenoides com a diminuição na incidência de câncer. As xantofilas luteína e zeaxantina são os principais carotenoides encontrados em grãos de milho e seu papel terapêutico relaciona-se 
ao aumento da função imune, à proteção contra a degeneração macular e ainda ao bloqueio do crescimento tumoral.

Esses antioxidantes absorvem radicais livres e inibem a cadeia de iniciação ou interrompem a cadeia de propagação das reações oxidativas promovidas pelos radicais (PODSEDEK, 2007).

Rios et al. (2008) relataram que ao longo dos anos, programas de melhoramento genético de milho priorizavam características agronômicas, principalmente relacionadas à produtividade. Entretanto, mesmo com a preferência dos produtores de aves por grãos de coloração amarelada, apenas recentemente observou-se um interesse frente à possibilidade de se encontrar no milho mais uma opção auxiliar às intervenções nutricionais existentes para o combate à hipovitaminose A na população humana.

Do ponto de vista químico, carotenoides são compostos polisoprenóides e podem ser divididos em dois grandes grupos: os carotenos ou carotenoides hidrocarbonos: compostos apenas de carbono e hidrogênio (ex. $\alpha$ e $\beta$-caroteno e licopeno) e as xantofilas: que são derivados oxigenados dos carotenos e contêm pelo menos uma função hidroxi, ceto, epóxi, metoxi ou ácido carboxílico (ex. luteína, zeaxantina e $\beta$-criptoxantina), sendo que $90 \%$ desses compostos, nos grãos, são constituídos por luteína e zeaxantina (RIOS et al., 2008; JANICKBUCKNER et al.,1999). A luteína e zeaxantina são xantofilas resultantes do processo de hidroxilação de $\alpha$-caroteno e $\beta$-caroteno, respectivamente, que possuem atividade de provitamina A. Durante a maturação dos frutos, a conversão da luteína e zeaxantina provoca uma diminuição nos níveis de $\alpha$-caroteno e $\beta$-caroteno (QUIRÓS; COSTA, 2006).

\subsection{MANEJO DA DIVERSIDADE GENÉTICA X SISTEMAS DE PRODUÇÃO}

Com a industrialização da agricultura, houve a simplificação dos sistemas agrícolas, a partir da substituição das variedades localmente adaptadas por cultivares de alto rendimento, adaptados especialmente a ambientes agrícolas com condições altamente controladas, estreitando a base genética das plantas cultivadas, conforme observado no trigo, milho e arroz (GALVÁN, 2000). Esse novo sistema ficou dependente de insumos industriais e da mecanização e se estendeu por várias regiões do mundo caracterizando-se pela associação de adubos químicos e agrotóxicos, mecanização da agricultura e disseminação de variedades melhoradas (SANTILLI, 2009). 
Machado et al. (2008) sustentam que a modernização da agricultura foi considerada a maior causa da erosão genética, comprometendo a capacidade das espécies de responder às mudanças climáticas e a todos os tipos de estresses bióticos e abióticos. Nesse sentido, com a perda de variedades locais, combinações únicas de genes (para diversas utilidades) desapareceram.

As propriedades dos pequenos agricultores geralmente constituem-se de ambientes marginais onde a agricultura é dominada por variações nas condições agroecológicas e socioeconômicas, sujeitas a estresses complexos e elevados custos e riscos de produção. (ALMEKINDERS; ELINGS, 2002). Machado e Machado (2007) relataram que, com isso, o correto manejo da diversidade genética de plantas nas comunidades de pequenos agricultores é uma importante estratégia para selecionar variedades adaptadas à sua região.

Dessas pequenas propriedades, diversas produzem o milho, sendo que aproximadamente $94 \%$ se caracterizam como agricultores familiares, tendo baixa utilização de insumos e o cultivo realizado em condições desfavoráveis para o bom desenvolvimento e melhores produtividades da cultura (DUARTE, 2000), produzindo apenas um terço da produção nacional desse cereal (IBGE, 2006).

Machado e Machado (2009) relataram que os sistemas agrícolas de base ecológica são aqueles que aplicam princípios ecológicos à produção, com a diversificação desses sistemas de modo a reduzir ou eliminar totalmente o uso de insumos químicos, otimizando os recursos da propriedade agrícola por meio de técnicas específicas de manejo de solos e das lavouras. Buscam a sustentabilidade ambiental, social e econômica, baseando-se na preservação e no respeito à terra, ao ambiente e ao homem, priorizando, inclusive, relações trabalhistas e de comércio justas.

A utilização de sistemas de manejo com maior nível tecnológico, caracterizados pelo uso de irrigação, pela maior aplicação de fertilizantes, pelo incremento na densidade de plantas, pela redução do espaçamento entrelinhas, pelo controle adequado de pragas, de plantas daninhas e de doenças pode contribuir para elevar o rendimento de grãos de milho no Brasil (ARGENTA et al., 2003). Entretanto, para os pequenos agricultores, o tamanho de sua propriedade, a impossibilidade de investimento inicial, e a vontade de ter sua própria semente podem inviabilizar totalmente tal ação.

Konzen (2003) mostrou que uma prática que pode melhorar tal estresse e reduzir o valor de produção utilizando técnicas citadas acima, podendo ser bastante eficiente, é a adubação orgânica. Tal adubação constitui uma poderosa e equilibrada forma de nutrição das plantas. Os resultados desse tipo de adubação em áreas de produção de grãos têm 
demonstrado produtividade igual ou superior aos encontrados em áreas com adubação química equivalente.

Borguini (2002) também relatou que o plantio de grãos e hortaliças em sistemas agroecológicos vem mostrando um grande crescimento e hoje é visto como estratégia para o desenvolvimento sustentável. Contudo, ainda são poucos os trabalhos científicos que comparam as características nutricionais e de qualidade dos alimentos cultivados nos sistemas agroecológico e convencional.

Cruz et al.(2007) relataram que há viabilidade técnica e econômica na produção de milho orgânico, principalmente quando são utilizadas variedades de polinização aberta, porém com as devidas adequações no manejo cultural para a melhora da eficiência dos sistemas de produção. Em seu trabalho, foram utilizados dois híbridos duplos, e estes não apresentaram resultados superiores às variedades.

A avaliação da diversidade genética do milho é de fácil compreensão pelos agricultores, onde a sua estrutura genética, com os cruzamentos ocorrendo de forma livre, são perfeitamente observáveis a campo. Isso resulta também no entendimento que o milho é uma espécie bastante suscetível à contaminação e erros de amostragem e que isso comumente provoca a perda de variabilidade. É fundamental, pois, que as variedades locais sejam submetidas à experimentação em diversos lugares por vários anos, para determinar o seu valor como variedade local e avaliar o seu potencial genético para melhoramento e posterior uso em diferentes agroecossistemas, considerando fatores limitantes, como é o caso da disponibilidade de $\mathrm{N}$, determinante em sistemas orgânicos e/ou agroecológicos (MACHADO et al., 2007).

Sobre essa baixa disponibilidade de N, Nunes (2006) também afirmou em sua pesquisa que esse é um dos principais fatores para a baixa produtividade da cultura do milho no Brasil, avaliada como estresse ambiental.

Carvalho (2000) relatou que a fertilidade do solo é um dos fatores ambientais que influenciam, diretamente, na composição química das plantas e das sementes. Os nutrientes que estão armazenados nos grãos suprirão os elementos necessários ao estabelecimento da plântula, em seus estágios iniciais. Entretanto, a intensidade com que esses nutrientes afetam o vigor das novas plantas parece depender, também, das condições às quais essas, que produziram as sementes, foram submetidas em se tratando do suprimento de nutrientes.

Para incrementar a eficiência técnica e econômica da produção de milho, é fundamental que se identifiquem sistemas de manejo compatíveis às características climáticas, edáficas, fundiárias e econômicas de cada região. Além disso, é necessário 
adequar-se as peculiaridades da cultivar ao sistema de manejo adotado. As avaliações técnica e econômica de diferentes sistemas de manejo são importantes, pois identificarão os fatores limitantes ao incremento do rendimento de grãos e da rentabilidade da cultura. Dimensionando-se o impacto dos fatores restritivos ao rendimento, poder-se-á definir estratégias de como superá-los ou minimizá-los através do manejo adequado das condições ambientais ou da seleção de cultivares mais bem adaptadas para cada ambiente (HORN et al., 2003; BARNI et al., 1995).

Prado (2008) relatou que no solo, o nitrogênio encontra-se na maior parte na forma orgânica (95\%) não assimilável pela planta, e o restante, na forma mineral assimilável, especialmente na forma de nitrato e amônio. Quando ocorre a passagem do $\mathrm{N}$ da forma orgânica para a mineral é denominada mineralização, compreendendo vários processos como aminização, amonificação e nitrificação.

Machado et al. (2011b) puderam concluir que, em diferentes épocas de análises de solo, há o predomínio da forma amoniacal do nitrogênio quando a produção do milho é realizada em sistemas agroecológicos, diferente dos sistemas convencionais de cultivo. Com isso, as variedades plantadas nesse sistema devem ser eficientes em absorver o nitrogênio na forma amoniacal $\left(\mathrm{NH}_{4}^{+}\right)$, já que as variedades melhoradas convencionalmente possuem mecanismo de eficiência na absorção de nitrogênio na forma de nitrato $\left(\mathrm{NO}_{3}{ }^{-}\right)$.

O preparo do solo tem como objetivo principal a melhoria de suas propriedades químicas, físicas e biológicas, visando aumentar o seu potencial produtivo. No entanto, o seu uso intensivo pode predispô-lo à formação de camadas compactadas, à redução da estabilidade dos agregados e ao aumento do número de microporos, aumentando a propensão à perda de solo (SOUZA, 1988).

O tipo de plantio mais utilizado para o milho em sistemas agroecológicos é o convencional. Esse tipo de preparo envolve aração e gradagens, ainda é utilizado na maioria das propriedades agrícolas do Brasil, com o objetivo básico de fornecer condições ótimas para a germinação, a emergência e o estabelecimento das plântulas. Além disso, o preparo convencional do solo permite também o controle mecânico da população inicial de plantas daninhas. Contudo, as operações motomecanizadas de preparo convencional constituem a principal forma de alteração de características físicas do solo, principalmente pela desestabilização da estrutura, que aumenta a erodibilidade da camada arável e pela compactação, que reduz da macroporosidade, a disponibilidade de água e ar no perfil, acarretando perda do potencial produtivo da área. Além disso, o preparo convencional 
provoca descontinuidade do sistema poroso, o que afeta a drenagem e aeração do perfil (EMBRAPA, 2012).

Basicamente, o preparo convencional do solo é realizado em duas etapas, que são o preparo primário e o secundário. O preparo primário tem como objetivo descompactar o solo. Consiste na utilização de arados ou grades pesadas, sendo utilizada também para incorporação de corretivos, de fertilizantes, de resíduos vegetais e de plantas daninhas, ou para a descompactação sub-superficial. Na incorporação de insumos ou de material vegetal, os equipamentos de discos são mais eficientes, pois permitem melhor mistura desses ao solo. Tem como desvantagem o potencial de causar compactação no perfil chamado de "pé de grade". A segunda etapa, chamada preparo secundário, consiste na operação de destorroamento e de nivelamento da camada arada de solo, por meio de gradagens do terreno (EMBRAPA, 2012). Todas as operações mecânicas, a começar pelo preparo do solo, devem ser executadas preferencialmente em nível.

Kluthcouski et al. (2000) afirmaram em seu trabalho que o rendimento médio de produtividade do milho foi significativamente superior quando foi utilizada a aração em relação ao plantio direto.

Os sistemas de produção de milho com a inclusão de adubos verdes proporcionam elevada cobertura e são efetivos no controle da erosão, reduzindo as perdas de solo, água e matéria orgânica. Com a utilização de leguminosas nos sistemas de produção, é possível reduzir pela metade, em alguns casos, a adubação nitrogenada mineral do milho (DEBARBA; AMADO, 1997). 


\section{OBJETIVOS}

\subsection{OBJETIVO GERAL}

Realizar a caracterização agronômica das plantas e avaliar o teor de carotenoides totais presente nos grãos de milho de quatro cultivares semeadas em propriedade conduzidas sob práticas agroecológicas.

\subsection{OBJETIVOS ESPECÍFICOS}

a) Avaliar caracteres agronômicos de quatro genótipos de milho (Sol da Manhã, Eldorado, PZ 240 e PZ 316) em duas propriedades distintas sob sistema agroecológico;

b) Analisar, em três épocas distintas, a relação entre o nitrogênio na forma amoniacal e nitrato durante o ciclo da planta de milho;

c) Extrair e determinar o conteúdo de compostos de carotenenoides totais nos grãos de milho de genótipos com base genética distinta;

d) Verificar a relação entre os caracteres agronômicos, a produção de milho e o teor de carotenoides totais presente nos grãos. 


\section{REFERENCIAS BIBLIOGRÁFICAS}

ALLARD, R.W. Princípios do melhoramento genético das plantas. São Paulo: Edgard Blücher, 1971. 381p.

ALMEKINDERS, C. J. M.; ELINGS, A. Collaborations of farmers and breeders; participatory crop improvement in perspective. Euphytica 122, 425-438, 2001 AMAN, R.; et al. A. Isolation of carotenoids from plant materials and dietary supplements by high-speed counter-current chromatography. A, v. 1074, p. 99-105, 2005.

ARGENTA, G.; et al. Adubação nitrogenada em milho pelo monitoramento do nível de nitrogênio na planta por meio do clorofilômetro. Revista Brasileira de Ciência do Solo, 27:109-119, 2003.

BALBINOT JR.; et al.. Contribuição de componentes de rendimento na produtividade de grãos em variedades de polinização aberta de milho. Revista Brasileira de Agrociência, Pelotas, v.11, n. 2, p. 161-166, abr-jun, 2005.

BARNI, N.A.; et al. Rendimento máximo do girassol com base na radiação solar e temperatura: II. Produção de fitomassa e rendimento de grãos. 1995 Pesquisa Agropecuária Gaúcha, v.1, n.2, p.201-216, 1995 BARTLEY, G.E.; SCOINIK, P.A. Plant carotenoids: pigments for photoprotection, visual, attraction, and human health. Plant Cell, v. 7, p. 1027-1038, 1995.

BATISTA, H. G. Para fugir de frete caro, milho vira etanol. Jornal O Globo. Sítio acessado em 23/08/2013, às 11:35h https://conteudoclippingmp. planejamento. gov.br/cadastros/noticias/2013/8/4/para-fugir-de-frete-caro-milho-vira-etanol. 
BERTINI, C. H. C. M. ; SCHUSTER, I. ; SEDIYAMA, T. ; BARROS, E. G. ; MOREIRA, M. A. . Determinação da diversidade genética em cultivares de algodoeiro herbáceo por marcadores microssatélites. In: IV Congresso Brasileiro de Algodão, 2003, Goiânia.

BISOGNIN, D.A. CIPRANDI, O.; MEIRELES, J. L.; GUIDOLIN, A. F. Potencial de variedades de polinização aberta de milho em diferentes condições adversas de ambiente. Pesquisa Agropecuária Gaúcha, v.3, p.29-34, 1997.

BOEF, W.S.; et al. (Orgs). Biodiversidade e agricultores: fortalecendo o manejo comunitário. Porto Alegre: LPM, 2007.

BORÉM, A. Melhoramento de espécies cultivadas. Viçosa: UFV, 1999. 817p.

BORÉM, A.; GIÚDICE, M.P. del. Cultivares transgênicos. In: GALVÃO, J.C.C.; MIRANDA, G.V. Tecnologia de produção do milho. 20.ed. Viçosa: UFV, v.1, p.13-53, 2004.

BORGUINI, R. G. Tomate (Lycopersicon esculentum Mill.) orgânico: o conteúdo nutricional e a opinião do consumidor. 2002. 110 f. Dissertação (Mestrado em Agronomia)-Escola Superior de Agricultura Luiz de Queiroz, Universidade de São Paulo, Piracicaba, 2002.

BUENO, L. C. de S. Melhoramento genético de plantas: princípios e procedimentos. 2. ed. Lavras: Ed. da UFLA, 2006, 319 p.

CHÁVES CABRERA, A. Uso de linhagens parcialmente endogâmicas S3 para a produção de híbridos simples de milho. Tese (Doutorado). Piracicaba, 2001, 123f.

CONAB, Indicadores da agropecuária. Disponível em: http://www.conab.gov.br/conteudos.php?a=1534\&t=2. Sítio acessado em 20/07/2014 às $22: 15 h$

COSTA, M.N. da. Análise dialélica das capacidades geral e específica de combinação utilizando técnicas uni e multivariadas de divergência genética em mamoneira (Ricinus communis L.). 2006. 132f. Tese (Doutorado em Agronomia). UFP, Areia, PB.

COSTA SANTOS, F. M. da. Capacidade de combinação de híbridos comerciais de milho visando à obtenção de híbridos de F2. Dissertação de mestrado IAC, Campinas, 2009. $78 f$. CRUZ, J. C.; FILHO, I. A. P., PEREIRA, F. T. F., ALVARENGA, R. C., KONZEN, E. A. Produção orgânica de grãos e silagem de milho. In: II Congresso Brasileiro de Agroecologia. Revista Brasileira de Agroecologia, v.2, n.1, fev. 2007.

CRUZ, J. C.; FILHO, I. A. P., OLIVEIRA, A. C., GUIMARÃES, L. J. M., QUEIROZ, L. R., MATRANGOLO, W. J. R., MOREIRA, J. A. A. Produtividade de variedades de milho em sistema orgânico de produção, Dez, 2009, Sete Lagoas, MG.

DAMODARAN, S.; PARKIN, K.; FENNEMA, O. R. Fennema's food chemistry. 4. ed. Boca Raton: CRC Press, 2008. 1144 p.

DEBARBA, L., AMADO, T. J. C. Desenvolvimento de sistemas de produção de milho no Sul do Brasil com características de sustentabilidade. Revista Brasileira de Ciência do Solo, Viçosa, 21:473-480, 1997. 
DUARTE, J. de O. Introdução e importância econômica do milho. In: CRUZ, J. C.; VERSIANI, R. P.; FERREIRA, M. T. R. (Ed.). Cultivo do milho. Sete Lagoas: Embrapa Milho e Sorgo, 2000 (Embrapa Milho e Sorgo, Sistemas de Produção, 1).

EAST, E.M. The distinction between development and heredity in breeding. Americam Naturalist, v. 43, p. 173-181, 1909.

EMBRAPA-SPI, Recomendações técnicas para o cultivo do milho, $2^{\circ}$ edição, Brasília DF 1996, 85-92p.

EMBRAPA MILHO E SORGO, Sistemas de produção 1, ISSN 1679-012X Versão Eletrônica - Out./2012. Acesso em http:// sistemasdeproducao.cnptia.embrapa.br/FontesHTML/Milho/CultivoMilho8ed/index.htm

EMCAPA. Manual técnico para a cultura do milho no estado do Espírito Santo. Vitória, ES.168p, 1996.

FALEIRO, F. G.; ANDRADE, S. R. M. Biotecnologia: estado da arte e aplicações na agropecuária. Planaltina, DF - Embrapa Cerrados, 2011. 730p.

FONTANA, J. D.; MENDES, S. V.; PERSIKE, D. S.; PERACETTA, L. F.; PASSOS, M. Carotenoides. Biotecnologia Ciência e Desenvolvimento, n. 13, p. 40-45, 2000.

FORD, R. H. Inharitence of kernel color in corn: explanations and investigations. The American Biology Teacher, Reston, v.6, n.3, p/ 181-188. 2000.

GALINAT, W.C. The origin of maize: grain of humanity. New York: New York Botanical Garden Journal, v. 44, p.3-12, 1995.

GALVÁN, G. Los recursos genéticos en el Uruguay, una visión desde la horticultura. In: La adaptación productiva del germoplasma local de cebolla y marrón, y su utilización en el desarrollo de cultivares. Argentina: Centro Regional Sur, 2000. p. 16-30.

GARCIA, J. C.; MATTOSO, M. J.; DUARTE, J. O.; CRUZ, J. C. Aspectos econômicos da produção e utilização do milho. Sete Lagoas, MG, Embrapa Milho e Sorgo, 2006.

GARCIA, G. de O.; FERREIRA, P. A.; FILHO, S. M.; SANTOS, C. E M. dos. Qualidade nutricional e fisiológica de sementes de milho oriundas de plantas submetidas ao estresse salino. Viçosa, MG, v.15, n.3, 282p. 2007.

GODOY, L.J.G. Manejo do nitrogênio em cobertura na cultura do milho (Zea mays L.) em solo arenoso baseado no índice relativo de clorofila. 2002. 94p. Dissertação (Mestrado em Agricultura) Faculdade de Ciências Agronômicas, Botucatu, 2002.

GUADAGNIN, C. A.; GUADAGNIN, C. M. I. Melhoramento participativo de variedades locais de milho nas associações de desenvolvimento das microbacias de Guaraciaba - SC. nov. 2009 Vol. 4 No. 2.

GUIMARÃES, P. E. O; et. al. BR 473: Variedade de milho amarelo com qualidade proteica melhorada (QPM). Embrapa Milho e Sorgo, Sete Lagoas, MG, dezembro, 2004. 
GUIMARÃES, P. G. Desempenho de híbridos simples de milho (Zea mays L.) e correlação entre heterose e divergência genética entre as linhagens parentais. 2007. 111f. Dissertação (Mestrado em Melhoramento Genético Vegetal) - Pós-GraduaçãoIAC,Campinas, 2007.

GUSSON, E. Uso e diversidade genética em populações naturais de biriba (Escweilera ovata [Cambess] Miers): Subsídios ao manejo e conservação da espécie. 107 p. Dissertação de mestrado, ESALQ, Piracicaba, 2003.

HALLAUER, A.R. Methods used in developing maize inbred lines. Bergamo, v.35, n.1, p.1$16,1990$.

HALLAUER, A. R.; MIRANDA FILHO, J. B. Quantative genetics in maize breeding. Iowa State Univ. Press, Ames, Iowa, 1988. 468p. HORN, D. et al. Cinética da absorção de potássio em genótipos de milho contrastantes quanto a variabilidade genética. In: REUNIÃO TÉCNICA CATARINENSE DE MILHO E FEIJÃO, 4, 2003, Lages. Resumos... Lages: Graphel, 2003. 383p. p.201-205.

IBGE, Censo agropecuário, Rio de Janeiro, 2006.

JANICK-BUCKNER, D. et al. Biochemical and ultra-structural analysis of the y10 mutant of maize. Journal of Heredity, Cary, v. 90, n. 5, p. 507-513, 1999.

JORNAL AGROCERES. São Paulo: AGROCERES, n.219. 1994.

KIMURA, M .K. C. N.; et al. Screening and HPLC methods for carotenoids in sweet potato, cassava and maize for plant breeding trials. Food Chemistry, Essex, v. 100 n. 4,p. 17341746, 2007.

KLUTHCOUSKI, J.; et al. Manejo do solo e o rendimento de soja, milho, feijão e arroz em plantio direto. 2000. Sítio disponível em http://www.agencia.cnptia.embrapa.br/recursos/jkscientiaID-FXKGgzLkOG.htm, acessado em 22/08/2013 às 10:19h.

KONZEN, E. A. Fertilização de lavoura e pastagem com dejetos de suínos e cama de aves. Sete Lagoas: Embrapa Milho e Sorgo, 2003. 19p.

KURZ, C.; CARLE, R.; SCHIEBER, A. Characterisation of carotenoids from apricots and pumpkins for the evaluation of fruit product authenticity. Food Chemistry, London, v. 110, p. 522-530, 2008.

LEMOS, M.A. et al. Avaliação de dez linhagens e seus híbridos de milho superdoce em um dialelo completo. Horticultura Brasileira, Brasília, v.20, n.2, p.167-170, 2002.

LEMOS, P.M.M; et al. Identificação e quantificação de carotenóides de sementes de variedades locais e crioulas de milho (Zea mays), desenvolvidas e cultivadas tradicionalmente por agricultores familiares de Anchieta (SC). In: REUNIÃO ANUAL DA SBPC, 58. 2006, Florianópolis. Anais... Florianópolis, 2006. (CD-ROM). 
LONDRES, F. Semente crioula: cuidar, multiplicar e partilhar. Passo Fundo: ASPTA, 2009. $78 \mathrm{p}$.

MACHADO, A. T., et al. Manejo da diversidade genética do milho e melhoramento participativo em comunidades agrícolas nos estados do Rio de Janeiro e Espírito Santo. Embrapa Cerrados, Planaltina - DF, 2002. 22 p.

MACHADO, A. T; MACHADO, C. T. T. Biodiversidade e Agricultores: fortalecendo o manejo comunitário/Walter Simon de Boef, et al., P. A., RS: L\&PM, 2007 p.93.

MACHADO, A. T; MACHADO, C. T. T. Manejo da diversidade genética do milho em sistemas agroecológicos. Planaltina, Embrapa Cerrados, 2009, 94p.

MACHADO, A. T. et al. Manejo da diversidade genética de milho em sistemas agroecológicos. 2007 Vol.1 No.1. p.1349.

MACHADO, A. T., MACHADO, C. T. T., NASS, L. L., Manejo sustentável da agrobiodiversidade nos biomas Cerrado e Caatinga com ênfase em comunidade rurais. Planaltina, 2011a. Brasília: Embrapa.

MACHADO, A. T., MACHADO, C. T. T., NASS, L. L., Manejo da diversidade genética e melhoramento participativo de milho em sistemas agroecológicos. 127-136, $2011 \mathrm{~b}$.

MAGALHÃES, P.C.; et al. Fisiologia do milho. Sete Lagoas. Embrapa Milho e Sorgo. 2002, 23p. (Circular Técnica).

MENEGALDO, J. G. A importância do milho na vida das pessoas, Embrapa Meio Norte, 2011. http://ainfo.cnptia.embrapa.br/digital/bitstream/item/34809/1/Importanciamilho.pdf. Acessado em 17/06/2013.

MENEGUETTI, G.A.; GIRARDI, J.L.; REGINATTO, J.C. Milho crioulo: tecnologia viável e sustentável. Agroecologia e desenvolvimento rural sustentável. Porto Alegre, v.3, n.1,2002.

MERCADANTE, A.Z.; AMAYA, D.B.R.; BRITTON, G. HPLC and mass spectrophotometric analysis of carotenoids from mango. Journal Agriculture Food Chemistry, Washington, v.45, p.120-123, 1997.

MIRANDA FILHO, J. B.; GORGULHO, E. P. Cruzamentos com testadores e dialelos. In: NASS, L. L.; VALOIS, A. C. C.; MELO, I. S. de; VALADARES-INGLIS, M. C. Recursos genéticos e melhoramento - Plantas. Rondonópolis: Fundação MT, 2001. p. 649-671.

NASS, L. L., et al. Recursos genéticos e melhoramento - Plantas. Rondonópolis: Fundação MT, 2001, 1183p.

NASS, L. L.; SANTOS, M. X.; PATERNIANI, E. Importância das coleções de milho e perspectivas de coleta. In: WALTER, B. M. T.; CAVALCANTI, B. T. Fundamentos para a coleta de germoplasma vegetal. Brasília: Embrapa Recursos Genéticos e Biotecnologia, 2005. p. 633 - 661. 
NUNES, J. A., Avaliação participativa de variedades locais e melhoradas de milho visando a eficiência do uso do nitrogênio. Programa de pós-graduação da CAPES, Espírito Santo, 2006. 67p.

OLIVEIRA JUNIOR, et al. Seleção de genótipos de milho mais promissores para o consumo in natura. Ciência e Tecnologia de Alimentos, Campinas, v.26, n.1, p. 159-165, jan.-mar. 2006.

PACHECO, C. A. P et al.Melhoramento da variedade de milho de alta qualidade proteica (QPM) BR 473. In: CONGRESSO NACIONAL DE MILHO E SORGO. A inovação tecnológica e a competividade no contexto dos mercados globalizados: Sete Lagoas: ABMS: Embrapa Milho e Sorgo; Uberlândia: Universidade Federal de Uberlandia, 2000.

PATERNIANI, M.E.A.G.Z. Use of heterosis in maize breeding: history, methods and perpectives. Crop Breeding and Applied Biotechnology, v.1, n.2 p.159-178, 2001.

PATERNIANI, E.; CAMPOS, M. S. Melhoramento do milho. In: BORÉM, A. (Ed.). Melhoramento de espécies cultivadas. Viçosa: UFV, 2005. p. 491-552.

PODSEDEK, A. Natural antioxidants and antioxidant capacity of Brassica vegetables: review. LWT-Food Sci. Technol, v. 40, p. 1-11, 2007.

PRADO, R. de M. Nutrição de plantas. São Paulo: UNESP, 2008. 408p.

RAMALHO R. A, Flores H, Accioly E, Saunders C. Associação entre deficiência de vitamina A e situação sociodemográfica de mães e recém-nascidos. Revista Associação Médica Brasileira. 2006. p. 170-175

RAPOSO, F. V. Seleção recorrente recíproca em populações derivadas de híbridos simples de milho. Lavras, 2002. 106p. Tese (Doutorado em Genética e Melhoramento de Plantas) - Universidade Federal de Lavras - UFLA.

REGITANO NETO, A; NASS, L. L., MIRANDA FILHO, J. B. Potential of twent extic germoplasms to improve Brazilian maize architeture. Brazilian Journal of Genetics, n.4. p.691-969, 1997.

RIOS, S. A. et al. Adaptabilidade e estabilidade de carotenoides em cultivares de milho. In: CONGRESSO NACIONAL DE MILHO E SORGO, 27. Londrina. Agroenergia, produção de alimentos e mudanças climáticas: desafios para milho e sorgo - trabalhos e palestras. [Londrina]: IAPAR; [Sete Lagoas]: Embrapa Milho e Sorgo, 2008.

ROCHA, M. M. O melhoramento participativo do feijão-caupi: uma experiência no sertão do Piauí. 2008, Disponível em http://www.agrosoft.org.br/agropag/103496.htm. Acessado em 14/08/2013 as $23: 15 \mathrm{~h}$.

ROSINHA, R.O. Estratégias competitivas e reestruturação da indústria de sementes no Brasil: análise do segmento do milho. 2000. 143p. Dissertação (Mestrado) - Universidade Federal de Minas Gerais, Belo Horizonte, 2000. 
SANGOI, L.; ERNANI, P. R.; SILVA, P. R. F. da; HORN, D., SCHIMITT; A.; SCHWEITZER, MOTTER, F. Rendimento de grãos e margem bruta de cultivares de milho com variabilidade genética contrastante em diferentes sistemas de manejo. Santa Maria, v.36, n.3, p.747-755, 2006.

SANTILLI, J. Agrobiodiversidade e direitos dos agricultores. In: RICARDO, B.; RICARDO, F. Povos indígenas no Brasil 2001-2005. São Paulo: ISA, 2009. p.100 - 103.

SHULL, G.H. A pure line method of corn breeding. Report "Americam Breeders Association”, Washington, v.5, p.51-59, 1909.

SILVA, M. L. C., COSTA, S. R., SANTANA, A. S., KOBLITZ, M. G. B. Compostos fenólicos, carotenoides e atividade antioxidante em produtos vegetais. Seminário: Ciências Agrárias, Londrina, v. 31, n. 3, p. 669-682, jul./set. 2010.

SOARES, A. C. A multifuncionalidade da agricultura da agricultura familiar. Proposta $\mathrm{n}^{\circ} 87$ fevereiro 2001. p. 43-45.

SOLERI, D.; SMITH, S.E. Rapid estimation of broad sense heritability of farmer-managed maize population in the Central Valleys of Oaxaca, Mexico, and implication for improvement. Euphytica, v. 128, p.105-119, 2002.

SOUZA, C. M. Efeito do uso contínuo de grade pesada sobre algumas características físicas e químicas de um Latossolo Vermelho-Amarelo distrófico, fase cerrado, e sobre o desenvolvimento das plantas e absorção de nutrientes pela cultura de soja. 1988. $105 \mathrm{f}$. Dissertação (Mestrado em Agronomia) - Univ. Federal de Viçosa, Viçosa, MG, 1988.

SOUZA JÚNIOR, C.L. Contribuições da genética quantitativa para o melhoramento de milho: passado. presente e futuro. In: V SIMPÓSIO DE ATUALIZAÇÃO EM GENÉTICA E MELHORAMENTO DE PLANTAS - GENÉTICA E MELHORAMENTO DO MILHO, 2001, Lavras. Anais... Lavras: UFLA, 2001. p. 26-34.

SOUZA, W. A., BOAS, O. M. G. da C. V. A deficiência de vitamina A no Brasil: um panorama. Revista Panamericana de Salud Pública, Washington, 2002. v. 12, n. 3, p. 173-179. SPRAGUE, G.F.; TATUM, L.A. General vs. specific combining ability in single crosses of corn. Journal of the American Society of Agronomy, v. 34, n. 10, p. 923-932, 1942.

VENCOVSKY, R. Herança quantitativa. In: PATERNIANI, E; VIÉGAS, G.P. Melhoramento e produção do milho. 2.ed. Campinas: Fund. Cargill. 1987. p. 137-214.

VITAMIN A FIELD SUPPORT PROJECT (VITAL). Tercer taller regional sobre deficiencias de vitamina A y otros micronutrientes en América Latina y el Caribe (Recife, Brasil). Arlington, Virgínia: VITAL/US Agency for International Development; 1993.

VOLPI, B. D. et al. Retenção de carotenoides após processamento via moagem a seco de grãos de milho biofortificado. XXVIII Congresso Nacional de Milho e Sorgo, 2010, Goiânia: CD-Rom

WALTON, N.J.; BROWN, D.E. Chemicals from plants: perspectives on plant secondary products. London, 1999, $425 \mathrm{p}$. 
WELTZIEN R., E.; SMITH, M.E.; MEITZNER, L.S.; SPERLING, L. Technical and institutional issues in participatory plant breeding-from the perspective of formal plant breeding: A global analysis of issues, results, and current experience. CGIAR Systemwide Program on Participatory Research and Gender Analysis for Technology Development and Institutional Innovation; (CIAT), 2000, Cali, CO. 229 p.

WORLD HEALTH ORGANIZATION, (WHO). Global prevalence of vitamim A deficiency in populations at risk 1995-2005. Geneva, 2009, Disponível em: http://whqlibdoc.WHO.int/publications/2009/9789241598019eng.pdf Acesso em 15/12/13 


\section{CAPÍTULO ÚNICO}

Caracterização agronômica de plantas e teor de carotenoides totais de genótipos de milho em sistema agroecológico. 


\section{RESUMO}

A cultura do milho é responsável por 7\% da energia consumida no mundo. Além disso é uma das principais fontes de carotenoides na alimentação humana. A presença de vitaminas, compostos fenólicos e carotenoides em seus grãos pode explicar a importância do consumo diário deste, além do seu envolvimento na manutenção da saúde do homem. A função antioxidante dos carotenoides desempenha um papel importante na redução do risco de câncer, catarata, ateriosclerose e no processo de envelhecimento. O presente trabalho teve como objetivo a caracterização agronômica e a comparação de teores de carotenoides totais em quatro cultivares de milho com base genética distintas, extraídos de seus grãos. Para tal, foram utilizadas as variedades de polinização aberta Sol da Manhã e Eldorado, além dos híbridos simples PZ 240 e triplo PZ 316. Para determinação do teor de carotenoides nos grãos, foi utilizado o método de extração e quantificação de carotenoides, encontrando teores médios de $9,50 \mu \mathrm{g} \mathrm{g}^{-1}, 4,39 \mu \mathrm{g} \mathrm{g}^{-1}, 3,92 \mu \mathrm{g} \mathrm{g}^{-1}$ e 4,13 $\mu \mathrm{g} \mathrm{g}^{-1}$ para as variedades Sol da Manhã e Eldorado, além dos híbridos PZ 240 e PZ 316, respectivamente. As análises estatísticas e estimativas de parâmetros genéticos foram realizadas com o auxílio dos softwares GENES e MSTAT, detectando diferença significativa $(\mathrm{P} \geq 0,05)$ para a variedade Sol da Manhã, com superioridade na média do teor de carotenoides. Os valores de produtividade mostraram que houve diferença significativa entre todas as cultivares analisadas. Não houve correlação entre as características produção de grãos, teor de carotenoides totais nos grãos e área da folha da espiga superior com nenhum outro parâmetro estudado. Altos valores de herdabilidade em sentido amplo $\left(\mathrm{H}^{2}\right)$ foram observados na maioria dos caracteres agronômicos avaliados. O uso de adubação rica em termofosfato e compostos de farelos aumentou o valor da relação entre as formas de nitrogênio amoniacal e nitrato, além de terem sido detectados valores expressivos de produção para as quatro cultivares.

Palavras-chave: Zea mays L.; melhoramento participativo; diversidade genética; carotenoides totais. 


\section{ABSTRACT}

Maize accounts for $7 \%$ of the energy consumed worldwide. Besides is a major source of carotenoids in the human diet. The presence of vitamins, carotenoids and phenolic compounds in the grains can explain the importance of daily consumption of this crop, in addition to its involvement in the maintenance of human health. The antioxidant function of carotenoids plays an important role in reducing the risk of cancer, cataracts, atherosclerosis and aging.This study aimed to agronomic and comparing levels of total carotenoids in four maize cultivars with different genetic background, taken from their grain. To achieve this, open pollinated varieties Sol da Manhã and Eldorado were used beyond simple hybrid triple PZ 240 and PZ 316. To determine the content of carotenoids in the grains, the method of extraction and quantification of carotenoids was used and found average levels $9.50 \mathrm{mg} \mathrm{g}-1$, $4.39 \mathrm{mg} \mathrm{g} \mathrm{-1,} 3.92 \mathrm{mg} g$-1and $4.13 \mathrm{mg}$ g -1for the Sol da Manhã and Eldorado varieties as well as hybrids PZ 240 and PZ 316, respectively. Statistical analyzes and estimates of genetic parameters were performed with the aid of the software GENES and MSTAT, detecting a significant difference $(P \geq 0.05)$ for the Sol da Manhã range, with higher average content of carotenoids. The productivity values showed a significant difference between the cultivars analyzed. There was no correlation between the characteristics of grain, total carotenoid content in grain and leaf area of the upper ear with any other parameter studied. High heritability in broad sense $\left(\mathrm{H}^{2}\right)$ were observed in most of the evaluated agronomic traits. The use of fertilizers rich in compounds thermophosphate and sharps increased the value of the relationship between the forms of ammonia and nitrate, as well as impressive production values for the four cultivars were detected.

Key Word: Zea mays L.; participatory breeding; genetic diversity; total carotenoids. 


\section{INTRODUÇÃ̃O}

Atualmente o Brasil é o terceiro maior produtor mundial de milho, perdendo apenas para os Estados Unidos e China. Sua produção está estimada em 79,9 milhões de toneladas (CONAB, 2014). Essa cultura é semeada em praticamente todo o país, nas mais diferentes regiões e com os mais diferentes sistemas de produção, invalidando qualquer tentativa de homogeneização de produção que se procure dar ao tema (EMBRAPA, 1996).

O milho pode garantir a segurança alimentar dos povos, mas depende de uma correta conservação e manejo da diversidade genética. A maior parte da falta de recursos alimentares provém de condições inadequadas de manutenção da agricultura familiar em várias regiões do Brasil (SOARES, 2001).

A sustentabilidade dos sistemas agrícolas também depende do correto manejo da diversidade genética de espécies e variedades de plantas. Segundo Machado et al. (2002), esse processo consiste em resgatar, avaliar, selecionar, conservar e caracterizar os recursos genéticos (MACHADO, et al., 2002).

A cultura do milho, em função do seu potencial nutritivo e da composição química, tem grande importância na economia mundial, sendo responsável por $7 \%$ da energia consumida no mundo (FAO, 2007). Este cereal é uma das principais fontes de carotenoides na alimentação humana. A presença de vitaminas, compostos fenólicos e carotenoides nos grãos do milho pode explicar a importância do consumo diário deste, além do seu envolvimento na manutenção da saúde do homem. Dentre os pigmentos ocorrentes nos organismos vivos, os carotenoides são os mais amplamente distribuídos, porém, o organismo humano não é capaz de sintetizá-los, obtendo esses retinoides (vitamina A e seus derivados) obrigatoriamente através da alimentação (LEMOS et al., 2006; GRUNE et al., 2005).

Diversas evidências sugerem uma relação inversa entre o consumo de produtos de origem vegetal e a incidência de doenças degenerativas em humanos. Isto se deve à presença de compostos bioativos nesses alimentos, tais como as vitaminas A, C e E, os (poli)fenóis e os pigmentos denominados carotenóides e antocianinas que exercem efeitos importantes na prevenção de algumas doenças (KRIS-ETHERTON et al., 2002).

Com relação à baixa ingestão dessa vitamina, estima-se que os carotenoides provenientes de vegetais possam fornecer aproximadamente $68 \%$ na dieta em termos mundiais, e $82 \%$ nos países desenvolvidos. Uma vantagem dos carotenoides é que somente 
são convertidos em vitamina A pelo organismo quando houver a necessidade, evitando seu acúmulo (SOUZA \& BOAS, 2002).

O papel biológico desempenhado pelos carotenoides nos tecidos vegetais está diretamente relacionado à presença ou ausência de atividade fotossintética no tecido em questão. Em todos os tecidos, estes compostos assumem um papel de proteção contra 31efeitos deletérios causados pela exposição à radiação UV e pelo surgimento de estresse oxidativo. Nas flores e frutos de algumas espécies são essenciais à atração de polinizadores e dispersores, sendo responsáveis não apenas pela coloração, mas também pelo sabor e aroma destes órgãos. Nas sementes, os carotenoides são essenciais à manutenção da via de síntese do ácido abscísico (ABA), um fitohormônio originado a partir da xantofila zeaxantina, após uma série de reações oxidativas (BARTLEY \& SCOLNIK, 1995; HOWITT \& POGSON, 2006; FARRÉ et al., 2010, citados por KUHNEN et al.,2011).

Nos tecidos de plantas comestíveis, existe grande variedade de carotenoides. Estudos recentes mostram que a função antioxidante dos carotenoides desempenha um papel importante na redução do risco de câncer, catarata, ateriosclerose e no processo de envelhecimento (DAMODARAN et al., 2008).

Dessa forma, este estudo teve como objetivo a caracterização agronômica de quatro cultivares de milho, sendo duas variedades de polinização aberta e dois híbridos, um simples e um duplo, além da mensuração de carotenóides totais nos grãos de milho dessas cultivares, semeadas em duas propriedades com práticas agroecológicas implantadas. 


\section{MATERIAL E MÉTODOS}

\subsection{LOCAL DE INSTALAÇÃO DOS EXPERIMENTOS}

O experimento foi semeado no período de 21 de outubro de 2013 e conduzido até março de 2014 no Sítio Corujinha do Cerrado, situado na região de Brazlândia - DF (Lat. $15^{\circ} 37^{\text {ee }} 07^{\prime}$ S S Long. $48^{\circ} 03^{\text {ee }} 51^{\prime \prime} \mathrm{W}$ ), estando a aproximadamente $47 \mathrm{~km}$ do centro de Brasília, altitude $980 \mathrm{~m}$. Predomina o Latossolo vermelho com textura argilosa.

O sítio possui produção totalmente orgânica e é certificada pelo centro de produção Mokiti Okada. No local são cultivadas as mais diversificadas hortaliças, cereais e frutas, além de plantas aromáticas. Os produtos são comercializados em feiras livres dentro de Brasília, restaurantes, supermercados e na CEASA do Distrito Federal.

\subsection{CARACTERIZAÇÃO DOS GENÓTIPOS UTILIZADOS NO EXPERIMENTO}

Os tratamentos avaliados foram quatro cultivares de milho, sendo duas variedades, BRS 4157 Sol da Manhã NF e Eldorado, ambas da Embrapa e dois híbridos, um simples PZ 240 e um triplo PZ 316, produzidos pela Primaiz Sementes Ltda.

Neste trabalho, procurou-se avaliar variedades melhoradas formalmente e de forma participativa, comparando-as fisicamente e quimicamente, com valores de carotenoides totais presentes em cada uma. As variedades melhoradas de forma participativa foram escolhidas por serem plantadas por agricultores e por terem se destacado em ensaios anteriores (MACHADO et al., 2011b). Os dois híbridos foram incluídos no ensaio por participarem do Ensaio Nacional de Milho no ano de 2013.

\subsubsection{Variedades melhoradas de forma participativa}

A variedade Sol da Manhã foi obtida através do melhoramento genético participativo, realizado na Comunidade Sol da Manhã em Seropédica - RJ. Possui variação de grãos duros e semiduros, alaranjados, com segregação para branco e predomínio de germoplasma Cateto, Eto e Duros do Caribe. É formada por 36 populações da América Central e da América do Sul (MACHADO et al., 2011a). 
Eldorado é também uma variedade proveniente do melhoramento genético participativo, com seis ciclos de seleção massal em sistema orgânico, realizado na Comunidade Sol da Manhã, Seropédica - RJ e no Sítio Alegria, Brazlândia - DF. Possui grãos dentados e semidentados, amarelos com segregação para branco e predomínio da raça Tuxpeño. Formada por populações do México, da América Central e da América do Sul (MACHADO et al., 2011a).

\subsubsection{Híbridos}

O híbrido PZ 240 foi obtido pela Empresa Primaiz Sementes e tem como principais características a adaptação em regiões tropicais e subtropicais, tendo alta sanidade dos grãos. É um hibrido simples e quando cultivado sob condições ideais para esta cultivar, sua altura é de $220 \mathrm{~cm}$ e altura de inserção de espiga $110 \mathrm{~cm}$, folhas semieretas, com florescimento em torno de 64 dias e maturação 135 dias. Possui grãos alaranjados e duros (PRIMAIZ, 2013).

O híbrido PZ 316, também obtido pela Primaiz Sementes, é recomendado para lavouras com alto investimento, possuindo adaptações para regiões tropicais e subtropicais quentes, com alto rendimento. Esse é um híbrido triplo, com altura de planta $210 \mathrm{~cm}$ e altura de espiga $120 \mathrm{~cm}$, folhas semieretas. Seu florescimento ocorre com 64 dias e sua maturação com 135 dias. Possui grãos amarelos e semidentados (PRIMAIZ, 2013).

\subsection{MONTAGEM DOS EXPERIMENTOS DO CAMPO / TRATAMENTOS}

O delineamento experimental utilizado foi de blocos ao acaso com três repetições, sendo avaliados duas variedades de polinização aberta e dois híbridos, um simples e um triplo. Foram realizados dois ensaios no período de safra de verão, no ano agrícola de 2013/2014, sendo um em Brazlândia - DF, semeado no dia 21 de outubro de 2013 e o outro em Pirenópolis - GO com semeadura feita no dia 16 de novembro de 2013. Em ambos os locais foram utilizados os mesmos métodos de adubação e semeadura.

Para o preparo do solo no experimento de Brazlândia, foi utilizado um microtrator de marca Yanmar ${ }^{\circledR}$ (Figura 1). Primeiramente a enxada rotativa incorporou os restos de cultura 
que havia no local e, depois trocou-se o implemento para a confecção dos sulcos, utilizando o sulcador. Em Pirenópolis, toda a área foi preparada com o uso de enxadas manuais e sulcador de arraste por animais (Figura 2).

A parcela experimental constitui-se de quatro fileiras de quatro metros cada, espaçadas entre si em um metro, com três repetições. Após o desbaste foram mantidas 28 plantas por fileira. A adubação de plantio foi feita com termofosfato, de nome comercial Ioorin ${ }^{\circledR}$, sendo 50 gramas por metro, totalizando $500 \mathrm{~kg} / \mathrm{ha}$ e composto de farelos ou "Bokashi®" que é um adubo sólido constituído de uma mistura de resíduos agroindustriais diversos como farinha de ossos, farelos de cereais e de oleaginosas que passam por uma fermentação aeróbica e anaeróbica no próprio sítio. Desse composto, foram utilizados $600 \mathrm{~kg} / \mathrm{ha}$, aproximadamente 60 gramas por metro linear. Aos 48 dias foi realizada uma capina manual entre as fileiras e uma adubação de cobertura somente com o composto de farelos da propriedade, sendo a quantidade a mesma do plantio.

Três coletas de solo foram realizadas: a primeira foi realizada antes da adubação e plantio do ensaio. Foram analisados matéria orgânica, nitrato, amônia, macronutrientes e micronutrientes. Passados 72 dias após o plantio, foi analisado o nitrogênio na forma de nitrato e amônia. Na colheita, repetiu-se a análise de nitrato e amônia.

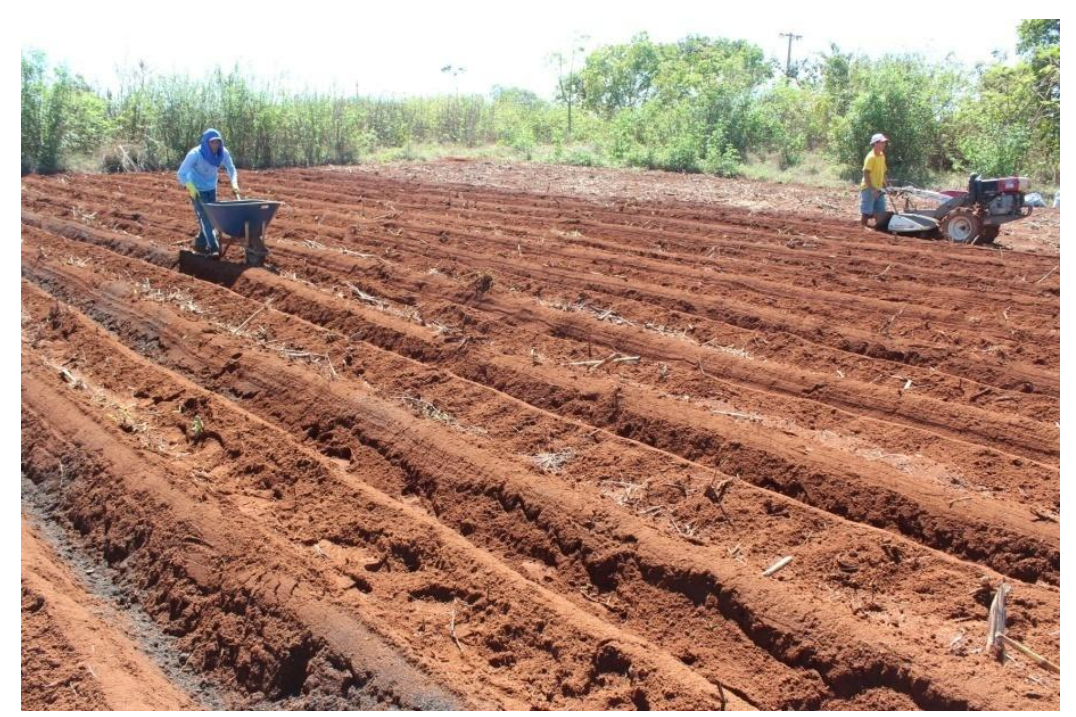

FIGURA 1: Preparo dos sulcos e colocação de adubo no Sítio Corujinha, Brazlândia -DF. 


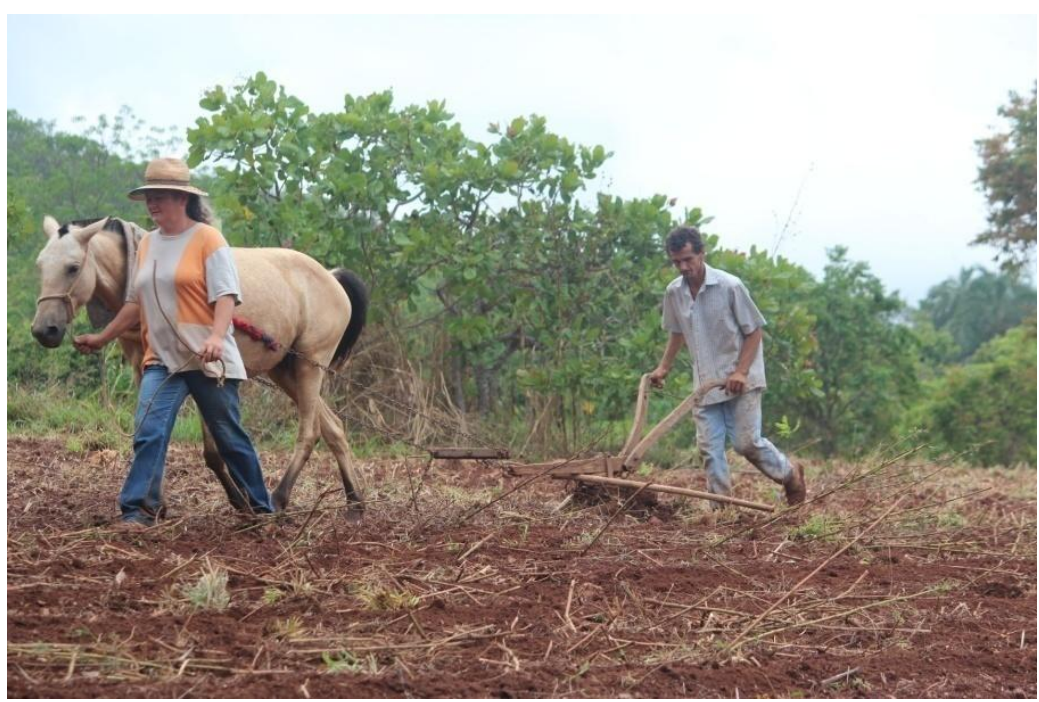

FIGURA 2: Uso de animal para arraste do sulcador no sítio Caxambú, Pirenópolis - GO

Para a análise dos caracteres agronômicos das plantas, utilizaram-se somente as duas fileiras internas de cada parcela.

\subsection{AVALIAÇÕES EXPERIMENTAIS}

\subsubsection{Avaliações de campo}

Os caracteres agronômicos foram avaliados em todas as quatro cultivares nas três repetições, anotados os dados das plantas competitivas dentro de cada parcela. A quantidade de plantas analisadas dependeu de cada caráter avaliado e estão descritos a seguir (Figura 3):

a) Altura de plantas, da base do solo até a base do pendão (10 plantas avaliadas);

b) Altura de espigas, anotadas da base do solo até a inserção da espiga superior (10 plantas avaliadas);

c) Comprimento da folha da espiga superior (10 plantas avaliadas);

d) Largura da folha da espiga superior - parte mais larga (10 plantas avaliadas);

e) Área da folha da espiga superior (10 plantas avaliadas);

f) Número de folhas por planta (10 plantas avaliadas);

g) Números de folhas acima da espiga principal (10 plantas avaliadas); 
h) Número de ramificações do pendão (10 plantas avaliadas);

i) Comprimento do pendão (10 plantas avaliadas);

j) Diâmetro do colmo - dois centímetros acima do primeiro colmo (10 plantas avaliadas);

k) Quantidade de nós em cada planta (10 plantas avaliadas);

1) Comprimento da espiga (10 plantas avaliadas);

m) Peso de 20 espigas (20 plantas avaliadas);

n) Peso dos grãos de 20 espigas (20 plantas avaliadas);

o) Número de grãos em 100 gramas (20 plantas avaliadas);

p) Peso hectolitro (20 plantas avaliadas);

q) Número de espigas por planta e parcela (em todas as plantas da parcela);

r) Número de espigas doentes por parcela (em todas as plantas da parcela).

s) Número de plantas quebradas abaixo da espiga principal por parcela;

t) Quantidade de plantas acamadas por parcela;

u) Posição da espiga - ereta, decumbente ou decumbente (10 plantas avaliadas).

As medições de altura, comprimento, largura e diâmetro foram medidas em centímetros e as de peso em quilogramas.

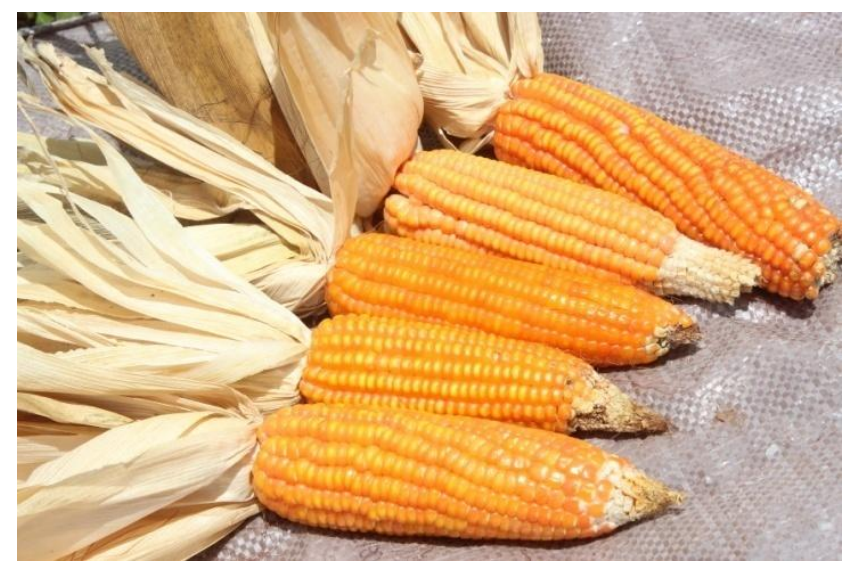

FIGURA 3: Avaliação dos descritores

\subsection{AVALIAÇÕES DE LABORATÓRIO}

A determinação dos valores de carotenoides dos grãos do experimento teve início na Universidade de Brasília, sendo finalizada na Universidade Federal de Santa Catarina. De cada parcela, foram separadas dez espigas e retirados os grãos da parte central de cada uma 
(Figura 4). Colocados em sacos identificados, foram encaminhados ao Laboratório de Análises de Alimentos da UnB e submetidos à estufa por 48 horas a $55^{\circ} \mathrm{C}$. Após, o material foi mantido dentro de um dessecador por uma hora, até que esfriasse sem contato com a umidade externa. Posteriormente, cada amostra foi triturada em um moinho (marca TECNAL, modelo TE 631) por aproximadamente 30 segundos em rotação de 27.000 RPM. Imediatamente, as amostras foram pesadas, embaladas em sacos plásticos e armazenadas em uma caixa térmica contendo gelo seco e encaminhadas ao Laboratório de Alimentos da UFSC para a realização da análise do teor de carotenoides total nos grãos de milho.

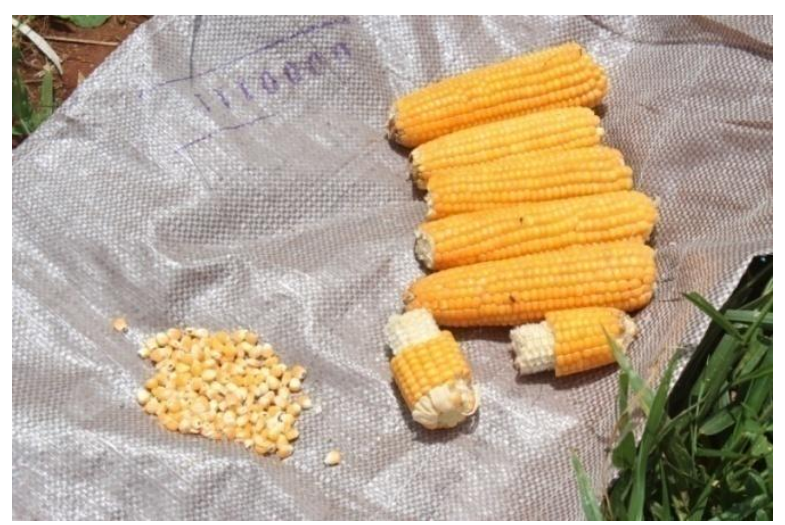

FIGURA 4: Retirada dos grãos para moagem da parte central da espiga.

A extração e a quantificação do teor de carotenoides totais foram realizadas a partir de uma amostra de $1 \mathrm{~g}$ de farinha, obtida da trituração de grãos de milho provenientes da parcela útil de cada tratamento. Após a trituração em moinho, a amostra de $1 \mathrm{~g}$ de farinha foi macerada em $20 \mathrm{~mL}$ de solução de hexano: acetona (v/v) contendo $100 \mathrm{~mL}$ de BHT (hidroxitolueno butilado) e submetida à agitação por $30 \mathrm{~min}$. A seguir, as amostras foram filtradas sob vácuo, o extrato centrifugado por 17 minutos a 4000 RPM, o solvente foi evaporado em rotaevaporador.

O extrato concentrado foi ressuspenso em $3 \mathrm{~mL}$ de hexano, lavado com $9 \mathrm{~mL}$ de água destilada (3x). O solvente foi evaporado em fluxo de nitrogênio e os extratos concentrados estocados em freezer $\left(-80^{\circ} \mathrm{C}\right)$. Após todas as extrações, os extratos concentrados foram ressuspensos em $3 \mathrm{~mL}$ de hexano, centrifugados por $10 \mathrm{~min}$ a $3200 \mathrm{RPM}$ e as leituras realizadas através da espectrofotometria UV-visível em absorbância de 450 ๆm (Aman et al., 2005). O teor de carotenóides totais foi calculado usando a fórmula de Lamber-Beer, utilizando-se o coeficiente de extinção molar $(\varepsilon)$ de $2590 \mathrm{M}^{-1} \mathrm{Cm}^{-1}$ (hexano) conforme previamente descrito por Kuhnen et al. (2011). 
Fórmula do teor de carotenóides totais $(\mathrm{CT})=$

$\mathrm{CT}=\mathrm{Abs} \times \mathrm{V} \times 10.000 / \mathrm{Ac}(1 \% ; 1 \mathrm{~cm}) \times \mathrm{P}$, onde:

Abs = absorvância a $450 \mathrm{~nm}$;

$\mathrm{V}=$ volume $(\mathrm{mL})$ do extrato;

Ac = Coeficiente de extinção molar (hexano) (2590);

$\mathrm{P}=$ peso da amostra $(\mathrm{g})$.

Os resultados foram expressos em $\mathrm{mg} / \mathrm{g}$ matéria fresca.

\subsection{ANÁLISES ESTATÍSTICAS}

O delineamento experimental utilizado no experimento foi em blocos ao acaso, com três repetições. Cada parcela experimental foi constituída de quatro fileiras com quatro metros cada e espaçadas entre si em um metro. Um estande final de 28 plantas por fileira foi mantido após o desbaste realizado quando as plantas possuíam, em média, 0,2 $\mathrm{m}$ de altura. Os dados foram submetidos a ANOVA e para o cálculo das variáveis estatísticas foram utilizados os programa estatísticos Excel (Microsoft Office, 2007), MSTAT (versão 1.0) e GENES (CRUZ, 2007). Foram considerados estatisticamente significativos os valores de $P$ menores que $5 \%$.

Para as análises de correlação linear (Pearson) entre todas as variáveis, basearam-se na significância de seus coeficientes. A classificação de intensidade da correlação para $p \leq 0,05$ é: muito forte $(r \pm 0,91$ a $\pm 1,00)$, forte $(r \pm 0,71$ a $\pm 0,9)$, média $(r \pm 0,51$ a $\pm 0,70)$ e fraca $(r \pm$ $0,31$ a $\pm 0,50)($ CARVALHO et al., 2004).

Foram estimados a herdabilidade no sentido amplo $\left(\mathrm{H}^{2}\right)$, o coeficiente de variação genético $\left(\mathrm{CV}_{\mathrm{g}}\right)$, e a relação entre o coeficiente de variação genético e ambiental $\left(\mathrm{CV}_{\mathrm{g}} / \mathrm{CV}_{\mathrm{e}}\right)$, utilizando-se o programa GENES para realização dos cálculos (CRUZ, 2007):

Variância fenotípica entre as médias dos tratamentos $-\hat{\sigma}_{f}^{2}=\frac{\mathrm{QMg}}{\mathrm{r}}$

Variância ambiental $-\hat{\sigma}_{e}^{2}=\frac{\mathrm{QMe}}{\mathrm{r}}$

Variância genotípica $-\hat{\sigma}_{g}^{2}=\frac{\mathrm{QMg}-\mathrm{QMe}}{\mathrm{r}}$

Herdabilidade ao nível de média $-H^{2}(\%)=\frac{\hat{\sigma}_{\mathrm{g}}^{2}}{\frac{\mathrm{QMg}}{\mathrm{r}}} 100$ 
Coeficiente de variação experimental - CVe $(\%)=\frac{\sqrt{\mathrm{QMe}}}{\overline{\mathrm{x}}} 100$,

onde $\overline{\mathrm{X}}=$ média do caráter considerado.

Coeficiente de variação genético $-\operatorname{CVg}(\%)=\frac{\sqrt{\hat{\sigma}_{g}^{2}}}{\bar{x}} 100$

\subsection{DESCRIÇÃO DO LOCAL}

\subsubsection{Sítio Corujinha}

O experimento foi semeado no período de 21 de outubro de 2013 e conduzido até março de 2014 no Sítio Corujinha do Cerrado, situado na região de Brazlândia - DF (Lat. $15^{\circ} 37^{\text {ee }} 07^{\prime \prime} \mathrm{S}$; Long. $48^{\circ} 03^{\text {ee }} 51^{\prime}$ W), estando a aproximadamente $47 \mathrm{~km}$ do centro de Brasília, altitude $980 \mathrm{~m}$. Predomina o Latossolo vermelho com textura argilosa.

O sítio possui produção totalmente orgânica e é certificada pelo centro de produção Mokiti Okada. No local são cultivadas as mais diversificadas hortaliças, cereais e frutas, além de plantas aromáticas. Os produtos são comercializados em feiras livres dentro de Brasília, restaurantes, supermercados e na CEASA do Distrito Federal.

\section{8.ÉPOCA DE FLORESCIMENTO}

O período de florescimento das cultivares do experimento realizado em Brazlândia teve início no dia 21 de outubro de 2013, alcançando seu pleno desenvolvimento em 29 de dezembro de 2013.

\subsection{ESTADO FITOSSANITÁRIO DAS PLANTAS}

Os experimentos foram vistoriados, pelo menos, duas vezes por semana. Houve ainda o cuidado do gerente de produção do Sítio Corujinha para com a área, avaliando para que não ocorressem possíveis ataques de pragas e doenças nas plantas. 
No experimento de Brazlândia, a precipitação ocorreu de forma homogênea durante todo o período, não havendo veranicos consideráveis na área cultivada. Porém, no experimento de Pirenópolis houve uma estiagem prolongada logo após a emergência das plântulas de milho, fazendo com que o todo o experimento fosse perdido. Não houve viabilidade para que o experimento fosse replantado.

\subsection{ANÁLISES LABORATORIAIS DE ADUBO E SOLO}

TABELA 1: Analise do adubo orgânico utilizado no sítio Corujinha - Brazlândia - DF. Material sólido constituído de uma mistura de resíduos agroindustriais diversos como farinha de ossos, farelos de cereais e de oleaginosas que passam por uma fermentação aeróbica ou anaeróbica no próprio sítio.

\begin{tabular}{|c|c|}
\hline Resultado em \% & \\
\hline $\mathrm{pH}$ em $\mathrm{CaCl} 2$ 0,01m & 8,4 \\
\hline Matéria Orgânica & 43,4 \\
\hline Nitrogênio total & 1,51 \\
\hline Fósforo total & 1,92 \\
\hline Potássio & 5,41 \\
\hline Cálcio & 7,22 \\
\hline Magnésio & 1,48 \\
\hline Enxofre & 0,6 \\
\hline Carbono Orgânico & 24,1 \\
\hline \multicolumn{2}{|l|}{ Resultado em PPM* } \\
\hline Boro & 149 \\
\hline Cobre & 9,2 \\
\hline Ferro & 106 \\
\hline Manganês & 8,13 \\
\hline Zinco & 40,1 \\
\hline Relação C/N & 16 \\
\hline
\end{tabular}

*PPM: Parte Por Milhão

TABELA 2: Resultados da análise laboratorial do solo do sítio Corujinha no ano agrícola de 2013/2014 - Época do plantio.

\begin{tabular}{cc}
\hline Macronutrientes & \\
\hline pH em água & 5,6 \\
$\mathrm{pH}$ em CaCl2 $0,01 \mathrm{~m}$ & 5,41 \\
Matéria Orgânica & $4,3 \mathrm{dag} / \mathrm{Kg}$ \\
Nitrogênio total & 1,7 \\
Fósforo total & $2,6 \mathrm{dag} / \mathrm{Kg}$
\end{tabular}




\begin{tabular}{cc} 
Potássio & $97,4 \mathrm{dag} / \mathrm{Kg}$ \\
Cálcio & $2,4 \mathrm{cmolc} / \mathrm{dm}^{3}$ \\
Magnésio & $0,7 \mathrm{cmolc} / \mathrm{dm}^{3}$ \\
Enxofre & $2 \mathrm{mg} / \mathrm{dm}^{3}$ \\
Carbono Orgânico & $2,50 \%$ \\
Al & $0,1 \mathrm{cmolc} / \mathrm{dm}^{3}$ \\
H+Al & $3,3 \mathrm{cmolc} / \mathrm{dm}^{3}$ \\
CTCtotal & $6,6 \mathrm{cmolc} / \mathrm{dm}^{3}$ \\
V & $48 \%$ \\
m & $3 \%$ \\
\hline Micronutrientes & \\
\hline Boro & $0,2 \mathrm{mg} / \mathrm{dm}^{3}$ \\
Cobre & $0,1 \mathrm{mg} / \mathrm{dm}^{3}$ \\
Ferro & $22,5 \mathrm{mg} / \mathrm{dm}^{3}$ \\
Manganês & $10,8 \mathrm{mg} / \mathrm{dm}^{3}$ \\
Zinco & $3,2 \mathrm{mg} / \mathrm{dm}^{3}$ \\
\hline Relações & \\
\hline Ca / Mg & $3,40 \%$ \\
Ca / K & $9,60 \%$ \\
Mg / K & $2,80 \%$ \\
\hline Saturação do Complexo de Troca \\
\hline K & $4 \%$ \\
Ca & $36 \%$ \\
Mg & $11 \%$ \\
Na & $0 \%$ \\
H + Al & $49 \%$ \\
\hline
\end{tabular}




\section{RESULTADOS E DISCUSSÃO}

Neste trabalho, procurou-se avaliar o desenvolvimento de um programa de melhoramento participativo com um programa de melhoramento formal, comparando duas variedades de polinização aberta adaptadas para sistemas agroecológicos e dois híbridos de milho, sendo um simples e outro triplo.

Localizado em Brazlândia, DF, o Sítio Corujinha, teve sua transição da forma convencional de produção para a forma agroecológica há mais de sete anos. Vale ressaltar, que no ano de 2012 foi realizado um plantio com a variedade Eldorado no mesmo local de onde foi instalado o presente experimento com o objetivo de apresentar o potencial desta variedade em sistemas orgânicos e conhecer as estratégicas de produção e comercialização de uma propriedade agroecológica a técnicos, produtores, estudantes e pesquisadores.

No experimento realizado no distrito de Caxambú, Pirenópolis - GO, não houve resultados, pois uma grande estiagem após a emergência das plântulas fez com que todo o experimento fosse perdido.

\subsection{RESULTADOS DE ANÁLISES LABORATORIAIS DE ADUBO E SOLO E DE PRODUTIVIDADE}

Conforme se observou na Figura 5, nas duas épocas posteriores ao plantio houve o predomínio do nitrogênio na forma amoniacal no solo. A disponibilidade de nitrogênio nas suas formas de amônia e nitrato é compreendida no local, com manejo agroecológico, indicando que, diferentemente dos sistemas convencionais (onde, segundo Machado et al. (2002) há o predomínio de $\mathrm{N}^{-} \mathrm{NO}_{3}{ }^{-}$), a maior disponibilidade de $\mathrm{N}$ se deu na forma de $\mathrm{NH}_{4}{ }^{+}$. 


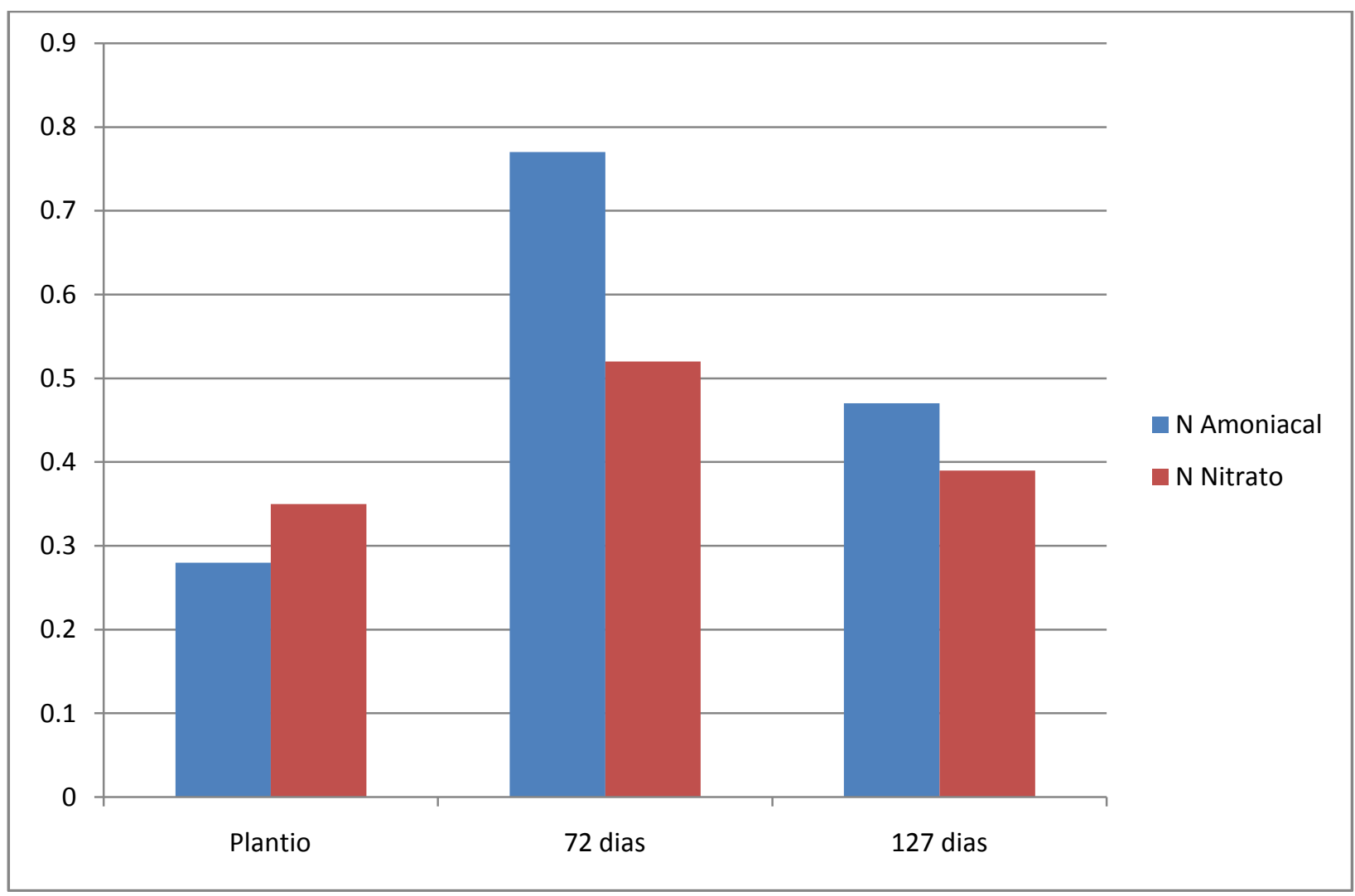

FIGURA 5: Teor de $\mathrm{N}(\mathrm{g} / \mathrm{Kg})$ no solo nas formas de amõnia e nitrato determinados em três épocas diferentes: No plantio, 72 dias após o plantio (72 DAP) e na colheita no Sítio Corujinha. 
Notou-se, também, que através da adubação, com o incremento de termofosfato e de compostos de farelos, houve um aumento no valor de $\mathrm{N}$ na forma amoniacal, saltando de 0,28 $\mathrm{g} / \mathrm{kg}$ (plantio) para $0,77 \mathrm{~g} / \mathrm{kg}$ (72 DAP) e na colheita o valor foi de $0,47 \mathrm{~g} / \mathrm{kg}$. Mostrando que esse tipo de adubação tendencia a forma de nitrogênio para amoniacal. Os valores de $\mathrm{N}$ nitrato foram 0,35 $\mathrm{g} / \mathrm{kg}$ (plantio), 0,52 $\mathrm{g} / \mathrm{kg}$ (72 DAP) e 0,39 $\mathrm{g} / \mathrm{kg}$ (colheita).

Machado et al. (2011b), relataram que o teor de nitrogênio no solo na forma de amônia e nitrato é diferente quando comparado com valores de agricultura convencional. O tipo de adubação utilizada no experimento fez com que houvesse um predomínio de nitrogênio na forma de $\mathrm{NH}_{4}{ }^{+}$, constatado a partir da época de floração. Tal fato se deu pela mineralização da matéria orgânica inserida no solo pelo adubo orgânico.

Com isso, ainda segundo os autores, as variedades plantadas nesse sistema devem ser eficientes em absorver o nitrogênio na forma amoniacal $\left(\mathrm{NH}_{4}{ }^{+}\right)$, já que as variedades melhoradas convencionalmente possuem mecanismo de eficiência na absorção de nitrogênio na forma de nitrato $\left(\mathrm{NO}_{3}{ }^{-}\right)$.

Com relação à produção das cultivares (Tabela 3), de maneira geral foi visto um destaque para a variedade Eldorado, com média de produção de $10.000 \mathrm{~kg} / \mathrm{ha}$. Segundo Machado et al. (2007), para esta variedade de polinização aberta conseguir valores altos de produção, a seleção vem sendo desenvolvida através de vários ciclos de seleção em sistema orgânico de produção. Diz ainda, que a formação de novas variedades é uma estratégia bastante importante para incrementar a diversidade genética do milho, visto que a maioria das variedades locais de milho no Brasil está em um verdadeiro processo de erosão genética.

A variedade Sol da Manhã, apesar da produção ter ficado um pouco menor, também obteve um valor expressivo em sua média de peso por hectare, chegando aos $8.550 \mathrm{~kg}$. Foi publicado pela Embrapa (2013) que seus processos de seleção também tiveram muitos ciclos e o maior objetivo deste melhoramento foi de atender aos agricultores que têm problemas de baixa fertilidade do solo relacionados ao baixo nível de nitrogênio. Os diversos ciclos de seleção foram realizados em ambientes com baixa fertilidade natural e com baixo nível de nitrogênio.

As outras duas cultivares de milho utilizadas no ensaio são dois híbridos produzidos por uma mesma empresa, sendo um simples e outro triplo. Suas características são boa adaptação em regiões tropicais e subtropicais, sendo utilizado em lavouras com alto rendimento de grãos por hectare (PRIMAIZ, 2013).

Outros fatores que também foram levados em consideração para essas altas produtividades, tanto das variedades de polinização aberta quanto para os híbridos, foi o fato 
de não ter ocorrido ataque de pragas e doenças significativas no experimento de Brazlândia, além de não ter ocorrido falta de água nas épocas que mais exigiram.

Na Tabela 4 são apresentados os dados relativos à produtividade média dos grãos das três repetições no local do experimento. O coeficiente de variação das quatro cultivares de milho foi de $2,48 \%$ e a média de produtividade entre as quatro cultivares ficou em $10.581 \mathrm{Kg} / \mathrm{ha}$. Ficou evidente que houve diferença significativa $(\mathrm{P} \geq 0,05)$ no quesito média da produção entre todas as cultivares de milho, uma vez que a diferença mínima significativa foi de 0,509 . 
TABELA 4. Médias de altura de planta (AP), em $\mathrm{cm}$, altura de espiga (AE), em $\mathrm{cm}$, e produção dos grãos por hectare (PESO), em $\mathrm{Kg} / \mathrm{ha}$, de cultivares de milho avaliadas em sistema orgânico de cultivo no ano agrícola de 2013/2014 no Sítio Corujinha, Brazlândia - DF.

\begin{tabular}{cccc}
\hline GENÓTIPOS & AP & AE & PESO \\
\hline Sol da manhã & $1,803 \mathrm{a}$ & $0,900 \mathrm{~b}$ & $8.550 \mathrm{~d}$ \\
Eldorado & $1,893 \mathrm{a}$ & $1,007 \mathrm{a}$ & $10.000 \mathrm{c}$ \\
PZ 240 & $1,530 \mathrm{~b}$ & $0,767 \mathrm{c}$ & $12.743 \mathrm{a}$ \\
PZ 316 & $1,593 \mathrm{~b}$ & $0,780 \mathrm{c}$ & $11.037 \mathrm{~b}$ \\
\hline Média & 1,704 & 0,863 & 10.581 \\
\hline${\text { CV }(\%)^{1}}^{2}$ & 2,47 & 5,00 & 2,48 \\
DMS $^{2}$ & 0,089 & 0,089 & 0,510 \\
\hline
\end{tabular}

${ }^{1}$ Para cada característica, as médias seguidas pela mesma letra na coluna pertencem ao mesmo grupo, ao nível de 5\% de significância, através da Diferença Mínima Significativa.

2 Diferença Mínima Significativa.

$\mathrm{CV}=$ Coeficiente de Variação 
Para Acosta et al. (2009) mesmo que o produtor precise adquirir as sementes das variedades de polinização aberta todos os anos, o custo da semente para se plantar um hectare com uma variedade chega a ser de 5 a 6 vezes menor do que o preço de um híbrido simples. Em seu trabalho, os resultados de análises de observação comparando híbridos e variedades de milho em dois níveis de adubação mostraram que, embora os híbridos sejam mais produtivos que as variedades em todas as situações, na ausência de fertilizantes no plantio e em cobertura, as maiores receitas líquidas foram proporcionadas pelas variedades.

De acordo com a publicação de Cruz et al. (2009), a variedade de polinização aberta Eldorado, juntamente com outras quatro variedades, não apresentou diferença significativa (P $\geq 0,05)$ de produção quando comparada a três híbridos duplos comerciais. Isso mostra a evolução no nível de produtividade das variedades de polinização aberta disponíveis no mercado atual e com perspectivas para o futuro, demonstrando ainda confiabilidade nos resultados apresentados pelo presente trabalho.

Convém ressaltar que Machado et al. (2002) mostraram que as variedades Sol da Manhã e Eldorado se destacaram entre diversas variedades em ensaios de competição realizados em Seropédica - RJ com baixos teores de nitrogênio, ressaltando que essas duas variedades foram selecionadas para eficiência para plantio com baixo uso de fósforo e nitrogênio, respectivamente.

Através dos dados fornecidos na Tabela 4, pode-se notar que os híbridos apresentaram porte de planta mais reduzido, consequência direta do processo de melhoramento, e as cultivares melhoradas de forma participativa se apresentaram, de forma geral, com alturas de planta e espiga maiores, comparadas com as melhoradas convencionalmente. $\mathrm{O}$ fato das variedades locais apresentarem valores maiores, destacando-se principalmente nas alturas de planta e espiga, justifica-se pelo tempo que estiveram adaptadas a agroecossistemas propícios para estas características, como por exemplo: ambientes agroflorestais e alta altitude (NUNES, 2006).

Diferenças significativas para altura de plantas e altura de espigas foram observadas para as variedades Sol da Manhã e Eldorado. Os dois híbridos não diferiram consideravelmente entre si, mas tiveram valores expressivos quando comparados às variedades. Ressalta-se que são variedades com germoplasma diferente, sendo a Sol da Manhã com predomínio das raças Cateto, Eto e Duros do Caribe e com grãos do tipo duro. Na variedade Eldorado predomina a raça Tuxpeño, com grãos do tipo dentado (MACHADO et al., 2003). Segundo Nunes (2006), geralmente, as variedades de milho que possuem grãos 
dentados têm uma maior produção por hectare que as de grãos duros. Entretanto, as de grãos duros são muito importantes em processos culinários, na agroindústria e na alimentação de animais.

Com relação aos caracteres agronômicos, de acordo com a Tabela 5, percebeu-se que houve diferença significativa $(\mathrm{P} \geq 0,05)$ para valores de área foliar $(\mathrm{AF})$, onde a cultivar $\mathrm{PZ}$ 316 obteve a maior média, com 1,250 $\mathrm{cm}^{2}$. A menor média de (AF) foi obtida pela variedade Sol da Manhã, 0,986 $\mathrm{cm}^{2}$. Entre as cultivares, não foram observadas diferenças significativas $(\mathrm{P} \geq 0,05)$ para os valores de comprimento do pendão $(\mathrm{CP})$. Para o item número de ramificações do pendão $(\mathrm{NR})$ foi observada diferença significativa $(\mathrm{P} \geq 0,05)$ entre as quatro cultivares, com valores de 15,867 para a variedade Sol da Manhã e 8,60 para o híbrido PZ 240. 
TABELA 5. Valores médios das três repetições para área foliar (AF), comprimento do pendão $(\mathrm{CP})$ e número de ramificações do pendão $(\mathrm{NR})$ de cultivares de milho avaliadas em sistema orgânico de cultivo no ano agrícola de 2013/2014 no Sítio Corujinha, Brazlândia - DF.

\begin{tabular}{lccc}
\hline GENÓTIPOS / CARACTERÍSTICAS & AF & CP & NR \\
\hline Sol da manhã & $0.986 \mathrm{~b}$ & $0.582 \mathrm{a}$ & $15.867 \mathrm{a}$ \\
Eldorado & $1.056 \mathrm{ab}$ & $0.559 \mathrm{a}$ & $12.633 \mathrm{~b}$ \\
PZ 240 & $1.168 \mathrm{ab}$ & $0.598 \mathrm{a}$ & $8.600 \mathrm{~d}$ \\
PZ 316 & $1.250 \mathrm{a}$ & $0.557 \mathrm{a}$ & $9.500 \mathrm{c}$ \\
\hline Média & 1,115 & 0,574 & 11,650 \\
\hline Cv (\%) & & 2,844 & 1,780 \\
DMS $^{2}$ & 6,620 & 0,046 & 0,586 \\
\hline
\end{tabular}

${ }^{1}$ Para cada característica, as médias seguidas pela mesma letra na coluna pertencem ao mesmo grupo, ao nível de 5\% de significância, através da Diferença Mínima Significativa.

2 Diferença Mínima Significativa.

CV = Coeficiente de Variação 


\subsection{TEORES DE CAROTENOIDES TOTAIS}

Para a mensuração de carotenoides totais presentes nos grãos de milho, os resultados mostraram que as análises de quantificação dos mesmos, que foram realizadas com as amostras de grãos de milho retiradas do Sítio Corujinha, possuem diferenças significativas estatísticas entre as populações $(\mathrm{P} \geq 0,05)$. A variedade Sol da Manhã se destacou com a melhor média $\left(9,507 \mathrm{\mu g} \mathrm{g}^{-1}\right)$, sendo a única a obter diferença significativa. Na Tabela 6 são apresentadas as concentrações $\left(\mu \mathrm{g}^{-1}\right)$ da fração quantificada de carotenoides totais precursores da vitamina $\mathrm{A}$, sendo as amostras dos grãos minimamente processadas após a colheita e rapidamente encaminhadas ao laboratório para realização das análises, evitando oxidação do material. 
TABELA 6 - Médias de carotenoides totais nos grãos $\left(\mu \mathrm{g} \mathrm{g}^{-1}\right)^{1}$ das cultivares de milho Sol da Manhã, Eldorado, PZ 240 e PZ 316 da safra 2013/2014 do sítio Corujinha, Brazlândia - DF.

\begin{tabular}{cc}
\hline GENÓTIPOS & TEOR $\left(\boldsymbol{\mu g} \mathbf{g}^{\mathbf{1}}\right)^{\mathbf{1}}$ \\
\hline Sol da Manhã & $9,507 \mathrm{a}$ \\
Eldorado & $4,367 \mathrm{~b}$ \\
PZ 240 & $3,92 \mathrm{~b}$ \\
PZ 316 & $4,133 \mathrm{~b}$ \\
\hline Média & 5,482 \\
\hline Cv $(\%)^{2}$ & 9,37 \\
DMS $^{3}$ & 1,027 \\
\hline
\end{tabular}

${ }^{1}$ Médias de três repetições, com extrações em triplicata;

2 Diferença Mínima Significativa;

${ }^{3} \mathrm{CV}=$ Coeficiente de Variação. 
As outras três cultivares tiveram médias parecidas, não havendo diferenças significativas nos teores de carotenoides entre elas $(P \geq 0,05)$. A variedade Sol da Manhã teve sua quantidade de teor de carotenoides superior em mais de duas vezes a quantidade da segunda colocada, variedade Eldorado, que teve média em 4,367 $\mu \mathrm{g} \mathrm{g}^{-1}$. Os híbridos PZ 240 e PZ 316 tiveram suas médias próximas, com diferença entre elas de $0,213 \mu \mathrm{g} \mathrm{g}^{-1}$. A diferença entre a variedade Sol da Manhã (maior média) e o híbrido PZ 240 (menor media) foi de $5,587 \mu \mathrm{g} \mathrm{g}^{-1}$. A característica mencionada não se correlacionou com nenhuma outra aqui estudada, como pode ser observado na Tabela 7.

A concentração média dos carotenoides da variedade de polinização aberta Sol da Manhã, além de ter tido a maior média quando comparada às outras analisadas, também mostrou valores superiores aos descritos por Kimura et al. (2007), onde a variedade BR 473 teve sua média de carotenoides totais em $9,17 \mu \mathrm{g} \mathrm{g}^{-1}$, ressaltando que esta última variedade teve sua composição química melhorada geneticamente para qualidade proteica, QPM.

Lemos et al. (2006) mostraram em sua pesquisa valores superiores aos encontrados neste trabalho, chegando a teores com $19,1 \mu \mathrm{g} / \mathrm{g}$, enquanto a menor concentração destes pigmentos foi observada em uma variedade com $2,92 \mu \mathrm{g} / \mathrm{g}$, demonstrando a grande diferença na composição química dos grãos de milho, refletindo a variabilidade genética presente nos materiais estudados.

Kuhnen et al. (2011) realizaram um experimento com 26 variedade de milho, em que a variedade MPA 01 continha teores de carotenoides nos grãos chegando a 10,80 $\mu \mathrm{g} / \mathrm{g}$ e a variedade Rosado 38, continha o menor teor, $0,12 \mu \mathrm{g} / \mathrm{g}$. A média entre as 26 variedades foi de aproximadamente 4,14 $\mu \mathrm{g} / \mathrm{g}$. Disseram ainda que o milho é amplamente consumido, mesmo em comunidades desfavorecidas, e que a introdução de variedades de milho como o MPA 01 à dieta, pode ser relevante, pois ajuda na diminuição de risco de doenças. Afirmam, ainda, que o alto teor de carotenoides mostra-se como uma característica particularmente importante para aumentar o valor comercial de grãos de milho de variedades específicas, bem como o uso destes genótipos em programas de melhoramento genético deste cereal.

Os resultados encontrados no presente trabalho estão de acordo com os registros prévios da literatura para teor de carotenoides totais em grãos de milho, sendo que uma grande amplitude de conteúdos $(0,5-23 \mu \mathrm{g} / \mathrm{g})$ tem sido relatada em outras publicações, o que parece estar relacionado com o potencial de cada genótipo (MANGELS et al., 1993).

Os grãos de milho da variedade Sol da Manhã mostram-se importantes para uso na alimentação humana e animal como fonte de provitamina A, poderá ter um provável uso na 
fabricação de fármacos, além de poder continuar sendo utilizado para o melhoramento genético de plantas.

\subsection{CORRELAÇÃO LINEAR DOS CARACTERES ANALISADOS}

Na Tabela 07, estão apresentados os coeficientes de correlação conjunta entre todas as características estudadas. Pode ser verificado que houve correlação significativa $(P \geq 0,05)$. entre as variáveis AP e AE $\left(r_{f}=98,97\right)$, AP e DC $\left(r_{f}=-95,48\right)$, AP e DECUMB $\left(r_{f}=98,98\right)$ e AP e PEND $\left(r_{\mathrm{f}}=95,40\right)$, indicando que a altura de plantas está diretamente relacionada positivamente com altura de espiga, negativamente com o diâmetro do colmo e positivamente com a posição da espiga decumbente e com a posição da espiga pendente. O mesmo ocorreu com as variáveis AE e DC $\left(r_{f}=-99,19\right)$, AE e DECUMB $\left(r_{f}=99,86\right)$, CF e NESP $\left(r_{f}=\right.$ 97,66), LF e $\operatorname{AF}\left(r_{f}=98,77\right)$, além de DC e DECUMB $\left(r_{f}=-98,57\right)$, indicando que estão diretamente relacionadas entre si. A característica PESO correlaciona-se de forma negativa com NR $\left(r_{f}=-95,93\right)$, indicando que a produção de grãos está diretamente relacionada com a quantidade de ramificações no pendão. Os demais caracteres não tiveram associação direta com a produtividade dos grãos. Pode-se notar que houve correlação não significativa entre as variáveis CAROT, AF, NFA, NOS, CP e ERET, mostrando que o teor de carotenoides totais nos grãos e a área da folha da espiga superior não se correlacionam com nenhuma característica.

Pode-se analisar, de acordo com a Tabela 7, que não há correlação significativa de área foliar (AF) com a produção (PESO) e nem com o teor de carotenoides nos grãos de milho (CAROT). Os valores para comprimento do pendão também não se correlacionaram com nenhuma outra característica e também não tiveram diferenças significativas entre as cultivares (Tabela 5). O número de ramificações do pendão se diferiu significativamente entre as quatro cultivares (Tabela 5) e ainda se correlacionou negativamente com a característica produção.

O número de ramificações do pendão foi analisado por Geraldi (1977), observando que esses caracteres são negativamente correlacionados com a produção de grãos. Pendões maiores provocam maior sombreamento das folhas bandeira, diminuindo assim a taxa fotossintética dessas folhas e, consequentemente, reduzindo o acúmulo de fotoassimilados pela planta. 
Rios et al. (2008) relataram que foram observadas correlações baixas e negativas entre produtividade dos grãos e carotenoides totais. O estudo teve 10 populações de milho semeadas em cinco ambientes distintos com 10 caracteres correlacionados.

A existência das correlações, tanto negativas quanto positivas entre as características de interesse agronômico, requer a utilização de métodos de seleção que as levem em consideração no momento da seleção dos genótipos superiores. 
TABELA 7 - Matriz de correlação linear (Pearson) entre os caracteres: teor de carotenoides totais nos grãos (CAROT), altura de plantas (AP), altura de espiga (AE), produção de grãos por hectare (PESO), comprimento da folha da espiga superior (CF), largura da folha da espiga superior (LF), área da folha da espiga superior (AF), número de folhas acima da espiga superior (NFA), número total de folhas (NF), quantidade de entrenós (NOS), número de espigas por planta (NESP), diâmetro do colmo (DC), comprimento do pendão $(\mathrm{CP})$, número de ramificações do pendão (NR), posição da espiga ereta (ERET), posição da espiga decumbente (DECUMB) e posição da espiga pendente (PEND), avaliadas em quatro cultivares de milho, em Brazlândia - DF. Ano agrícola 2013/2014.

\begin{tabular}{|c|c|c|c|c|c|c|c|c|c|c|c|c|c|c|c|c|}
\hline Variáveis & $\mathbf{A P}$ & $\mathbf{A E}$ & PESO & $\mathbf{C F}$ & $\mathbf{L F}$ & $\mathbf{A F}$ & NFA & NF & NOS & NESP & DC & $\mathbf{C P}$ & NR & ERET (\%) & $\begin{array}{c}\text { DECUMB } \\
(\%)\end{array}$ & PEND (\%) \\
\hline CAROT & $42.73^{\mathrm{ns}}$ & $30.18^{\mathrm{ns}}$ & $-80.63^{\mathrm{ns}}$ & $-42.32^{\mathrm{ns}}$ & $-73.55^{\mathrm{ns}}$ & $-75.90^{\mathrm{ns}}$ & $30.51^{\mathrm{ns}}$ & $-21.81^{\mathrm{ns}}$ & $-71.35^{\mathrm{ns}}$ & $-45.82^{\mathrm{ns}}$ & $-16.76^{\mathrm{ns}}$ & $22.72^{\mathrm{ns}}$ & $88.42^{\mathrm{ns}}$ & $-68.29^{\mathrm{ns}}$ & $34.44^{\mathrm{ns}}$ & $66.86^{\mathrm{ns}}$ \\
\hline $\mathbf{A P}$ & - & $98.97 *$ & $-80.24^{\mathrm{ns}}$ & $-83.37^{\mathrm{ns}}$ & $-69.73^{\mathrm{ns}}$ & $-79.84^{\mathrm{ns}}$ & $-4.00^{\mathrm{ns}}$ & $10.86^{\mathrm{ns}}$ & $33.04^{\mathrm{ns}}$ & $-72.52^{\mathrm{ns}}$ & $-95.48 *$ & $-43.24^{\mathrm{ns}}$ & $79.92^{\mathrm{ns}}$ & $-94.61^{\mathrm{ns}}$ & $98.98^{*}$ & $95.40^{*}$ \\
\hline $\mathbf{A E}$ & - & - & $-30.58^{\mathrm{ns}}$ & $-76.35^{\mathrm{ns}}$ & $-66.83^{\mathrm{ns}}$ & $-75.83^{\mathrm{ns}}$ & $-17.81^{\mathrm{ns}}$ & $5.73^{\mathrm{ns}}$ & $45.31^{\mathrm{ns}}$ & $-62.34^{\mathrm{ns}}$ & $-99.19 * *$ & $-41.87^{\mathrm{ns}}$ & $70.43^{\mathrm{ns}}$ & $-89.92^{\mathrm{ns}}$ & $99.86 * *$ & $90.85^{\mathrm{ns}}$ \\
\hline PESO & - & - & - & $87.33^{\mathrm{ns}}$ & $64.88^{\mathrm{ns}}$ & $76.21^{\mathrm{ns}}$ & $-43.20^{\mathrm{ns}}$ & $-23.47^{\mathrm{ns}}$ & $23.22^{\mathrm{ns}}$ & $90.91^{\mathrm{ns}}$ & $58.19^{\mathrm{ns}}$ & $35.69^{\mathrm{ns}}$ & $-95.93 *$ & $88.27^{\mathrm{ns}}$ & $-70.50^{\mathrm{ns}}$ & $-88.26^{\mathrm{ns}}$ \\
\hline CF & - & - & - & - & $33.31^{\mathrm{ns}}$ & $49.04^{\mathrm{ns}}$ & $-49.68^{\mathrm{ns}}$ & $-58.57^{\mathrm{ns}}$ & $-20.57^{\mathrm{ns}}$ & $97.66 *$ & $69.84^{\mathrm{ns}}$ & $75.47^{\mathrm{ns}}$ & $-72.19^{\mathrm{ns}}$ & $74.80^{\mathrm{ns}}$ & $-74.12^{\mathrm{ns}}$ & $-75.87^{\mathrm{ns}}$ \\
\hline $\mathbf{L F}$ & - & - & - & - & - & $98.77 *$ & $35.24^{\mathrm{ns}}$ & $43.40^{\mathrm{ns}}$ & $23.10^{\mathrm{ns}}$ & $29.99^{\mathrm{ns}}$ & $60.36^{\mathrm{ns}}$ & $-33.05^{\mathrm{ns}}$ & $-83.77^{\mathrm{ns}}$ & $86.92^{\mathrm{ns}}$ & $-71.74^{\mathrm{ns}}$ & $-85.84^{\mathrm{ns}}$ \\
\hline $\mathbf{A F}$ & - & - & - & - & - & - & $23.50^{\mathrm{ns}}$ & $41.40^{\mathrm{ns}}$ & $17.95^{\mathrm{ns}}$ & $45.41^{\mathrm{ns}}$ & $68.62^{\mathrm{ns}}$ & $-16.97^{\mathrm{ns}}$ & $-90.98^{\mathrm{ns}}$ & $94.38^{\mathrm{ns}}$ & $-79.95^{\mathrm{ns}}$ & $-93.58^{\mathrm{ns}}$ \\
\hline NFA & - & - & - & - & - & - & - & $78.85^{\mathrm{ns}}$ & $-35.66^{\mathrm{ns}}$ & $-65.75^{\mathrm{ns}}$ & $26.77^{\mathrm{ns}}$ & $-44.31^{\mathrm{ns}}$ & $20.63^{\mathrm{ns}}$ & $3.56^{\mathrm{ns}}$ & $-20.55^{\mathrm{ns}}$ & $-3.12^{\mathrm{ns}}$ \\
\hline NF & - & - & - & - & - & - & - & - & $-29.48^{\mathrm{ns}}$ & $-61.00^{\mathrm{ns}}$ & $-4.54^{\mathrm{ns}}$ & $-91.86^{\mathrm{ns}}$ & $-6.89^{\mathrm{ns}}$ & $10.35^{\mathrm{ns}}$ & $-0.78^{\mathrm{ns}}$ & $-8.39^{\mathrm{ns}}$ \\
\hline NÓS & - & - & - & - & - & - & - & - & - & $1.47^{\mathrm{ns}}$ & $-42.97^{\mathrm{ns}}$ & $-44.49^{\mathrm{ns}}$ & $-30.90^{\mathrm{ns}}$ & $-1.89^{\mathrm{ns}}$ & $40.81^{\mathrm{ns}}$ & $3.84^{\mathrm{ns}}$ \\
\hline NESP & - & - & - & - & - & - & - & - & - & - & $46.76^{\mathrm{ns}}$ & $69.72^{\mathrm{ns}}$ & $-74.73^{\mathrm{ns}}$ & $69.14^{\mathrm{ns}}$ & $-60.56^{\mathrm{ns}}$ & $-69.99^{\mathrm{ns}}$ \\
\hline DC & - & - & - & - & - & - & - & - & - & - & - & $42.67^{\mathrm{ns}}$ & $59.39^{\mathrm{ns}}$ & $82.88^{\mathrm{ns}}$ & $-98.57 *$ & $-83.97^{\mathrm{ns}}$ \\
\hline $\mathbf{C P}$ & - & - & - & - & - & - & - & - & - & - & - & - & $-9.79^{\mathrm{ns}}$ & $18.80^{\mathrm{ns}}$ & $-36.10^{\mathrm{ns}}$ & $-20.95^{\mathrm{ns}}$ \\
\hline NR & - & - & - & - & - & - & - & - & - & - & - & - & - & $-94.08^{\mathrm{ns}}$ & $73.28^{\mathrm{ns}}$ & $93.52^{\mathrm{ns}}$ \\
\hline ERET & - & - & - & - & - & - & - & - & - & - & - & - & - & - & - & - \\
\hline DECUMB & - & - & - & - & - & - & - & - & - & - & - & - & - & - & - & - \\
\hline
\end{tabular}

NS = não significativo; $*$ = significativo a $5 \%$ de probabilidade; $* *$ = significativo a $1 \%$ de probabilidade pelo teste $\mathrm{t}$. 


\subsection{PARÂMETROS GENÉTICOS}

As estimativas de parâmetros genéticos para as variáveis analisadas estão apresentadas na Tabela 8. Observou-se que as estimativas de herdabilidade oscilaram de $0 \%$ a $99,86 \%$. De forma geral, os caracteres avaliados obtiveram coeficientes de herdabilidade no sentido amplo superior a $60 \%$, dando um indicativo de que a variância ambiental não foi pronunciada. As menores herdabilidades foram observadas para as características número total de folhas e quantidade de nós por planta, com valores de 37,09\% e $0 \%$ respectivamente. Os altos valores da herdabilidade mostrados na Tabela 8 podem dar uma previsibilidade de quais serão os efeitos da seleção, pois grande parte da sua variação fenotípica é resultado de sua variação genética aditiva.

A utilização do coeficiente de variação genético $\left(\mathrm{CV}_{\mathrm{g}}\right)$ possibilitou a comparação da variabilidade genética entre as diferentes características analisadas. Verificou-se que os valores obtidos para o $\mathrm{CV}_{\mathrm{g}}$ variaram de 0 a $88,82 \%$. A maioria dos caracteres analisados teve valores abaixo dos 30\%, revelando uma baixa variabilidade genética entre os genótipos para as características avaliadas. Apenas as características carotenoides e posições da espiga tiveram valores mais elevados.

A relação entre $\mathrm{CV}_{\mathrm{g}} / \mathrm{CV}$, denominada de índice de variação (Iv), é um importante indicador das possibilidades de sucesso na obtenção de ganhos genéticos por meio de seleção. A situação é favorável quando os valores são maiores que 1,0. Pode ser observado que somente uma característica não obteve essa nota, quantidade de nós por planta. O maior valor da relação foi de 15,89\% para a característica número de ramificações do pendão, demonstrando um baixo efeito do ambiente nessas características, sendo bastante favorável aos processos de seleção (VENCOVSKY, 1987). 
TABELA 8. Estimativas da herdabilidade no sentido amplo $\left(\mathrm{H}_{\mathrm{a}}{ }^{2}\right)$, coeficiente de variação genético $\left(\mathrm{CV}_{\mathrm{g}}\right)$ e razão entre coeficiente de variação genético e ambiental $\left(\mathrm{CV}_{\mathrm{g}} / \mathrm{CV}_{\mathrm{e}}\right)$, para os caracteres: teor de carotenoides totais nos grãos (CAROT), altura de plantas (AP), altura de espiga (AE), produção de grãos por hectare (PESO), comprimento da folha da espiga superior (CF), largura da folha da espiga superior (LF), área da folha da espiga superior (AF), número de folhas acima da espiga superior (NFA), número total de folhas (NF), quantidade de entrenós (NOS), número de espigas por planta (NESP), diâmetro do colmo (DC), comprimento do pendão (CP), número de ramificações do pendão (NR), posição da espiga ereta (ERET), posição da espiga decumbente (DECUMB) e posição da espiga pendente (PEND), avaliadas em quatro cultivares de milho, em Brazlândia - DF. Ano agrícola 2013/2014.

\begin{tabular}{|c|c|c|c|c|c|c|c|c|c|c|c|c|c|c|c|c|c|}
\hline PARÂMETROS & CAROT & $\mathbf{A P}$ & $\mathbf{A E}$ & PESO & $\mathbf{C F}$ & $\mathbf{L F}$ & $\mathbf{A F}$ & NFA & NF & NOS & NESP & DC & $\mathbf{C P}$ & NR & $\begin{array}{l}\text { ERET } \\
(\%)\end{array}$ & $\begin{array}{l}\text { DECUMB } \\
(\%)\end{array}$ & $\begin{array}{l}\text { PEND } \\
(\%)\end{array}$ \\
\hline $\mathbf{H}_{\mathrm{a}}^{2}(\%)$ & 98.781 & 98.115 & 94.798 & 99.305 & 61.290 & 86.970 & 86.700 & 92.307 & 37.090 & 0 & 86.413 & 75.000 & 77.305 & 99.868 & 99.806 & 85.418 & 99.836 \\
\hline CVg (\%) & 48.706 & 9.956 & 12.510 & 16.664 & 1.486 & 9.124 & 9.760 & 2.102 & 2.351 & 0 & 13.414 & 4.255 & 3.030 & 28.308 & 66.881 & 35.494 & 88.823 \\
\hline $\mathrm{CVg} / \mathrm{CVe}$ & 5.197 & 4.166 & 2.464 & 6.904 & 0.726 & 1.491 & 1.474 & 2.000 & 0.443 & 0 & 1.465 & 1.000 & 1.065 & 15.894 & 13.107 & 1.397 & 14.263 \\
\hline
\end{tabular}




\section{CONCLUSÕES}

a) O incremento de adubação rica em termofosfato e em compostos de farelos no plantio e de cobertura (72 DAP) aumenta o valor da relação entre nitrogênio na forma amoniacal e nitrato durante o ciclo da planta de milho;

b) São detectados valores expressivos de produtividade para as quatro cultivares (variedades de polinização aberta e híbridos) quando semeadas em local com agroecologia implantada e adubadas com termofosfato e com compostos de farelos;

c) Os quatro genótipos avaliados mostraram-se como boas fontes de carotenoides. A variedade de polinização aberta Sol da Manhã se destacou, podendo ser utilizada em indústria farmacêutica e de alimento, suprir as recomendações de vitamina A para adultos e crianças além de poder representar uma fonte de renda a mais para os pequenos agricultores;

d) O valor da área da folha superior à espiga não se relaciona com o teor de carotenoides presente nos grãos de milho nem mesmo com a produção;

e) Pela análise dos coeficientes de herdabilidade no sentido amplo, ficou evidenciada variância genética pronunciada para as características avaliadas, podendo dar previsibilidade aos efeitos da seleção. 


\section{REFERÊNCIAS}

ACOSTA, A, et al. Resultados de unidades de observação de híbridos e variedades de milho em dois níveis de adubação de base e de cobertura. In: CRUZ, J. C.; FILHO, I. A. P., OLIVEIRA, A. C., GUIMARÃES, L. J. M., QUEIROZ, L. R., MATRANGOLO, W. J. R., MOREIRA, J. A. A. Produtividade de variedades de milho em sistema orgânico de produção, Dez, 2009.

BUENO, L. C. de S. Melhoramento genético de plantas: princípios e procedimentos. 2. ed. Lavras: Ed. da UFLA, 2006, 319 p.

CARVALHO, F. I. F. et al. Estimativas e implicações da correlação no melhoramento vegetal. Pelotas: Ed. Universitária da UFPel, 2004. 142 p.

CONAB, Indicadores da agropecuária. Disponível em: http://www.conab.gov.br/conteudos.php?a=1534\&t=2. Acesso em 20/07/2014.

CRUZ, C. D. Programa GENES - versão Windows (2004.2.1). Viçosa, UFV, 2007. 642p.

CRUZ, J. C.; FILHO, I. A. P., OLIVEIRA, A. C., GUIMARÃES, L. J. M., QUEIROZ, L. R., MATRANGOLO, W. J. R., MOREIRA, J. A. A. Produtividade de variedades de milho em Sistema orgânico de produção, Dez, 2009, Sete Lagoas.

EMBRAPA-SPI, Recomendações técnicas para o cultivo do milho, $2^{\circ}$ edição, Brasília, 1996, 85-92p.

EMBRAPA MILHO E SORGO, Sistemas de produção 1, Versão Eletrônica - $8^{\text {a }}$ Ed. Out./2012. Sítio acessado em 22/08/2013 às 11:14h http:// sistemasdeproducao.cnptia.embrapa.br/FontesHTML/Milho/CultivoMilho8ed/index.htm

FAO. Statistical Database. Disponível em: http://faostat.fao.org/site/346/default.aspx, 2007. Citado por: KUHNEN, S.; et al. Carotenoid and anthocyanin contents of grains of Brazilian maize landraces. Journal of the Science of Food and Agriculture, v. 91, p. 1548-1553, 2011.

GERALDI, I.O. Estimação de parâmetros genéticos de caracteres do pendão em milho (Zea mays L.) e perspectivas de melhoramento. Piracicaba: ESALQ, 1977. 103p. Tese Mestrado. 
KIMURA, M .K. C. N.; et al. Screening and HPLC methods for carotenoids in sweet potato, cassava and maize for plant breeding trials. Food Chemistry, Essex, v. 100 n. 4,p. 17341746, 2007.

KRIS-ETHERTON, P.M.; HECKER, K.D.; BONANOME, A.; COVAL, S.M.; BINKOSKI, A.E.; HILPERT, K.F.; GRIEL, A.E.; ETHERTON, T.Y.D. Bioactive Compounds in Foods: Their Role in the Prevention of Cardiovascular Disease and Cancer. The American Journal of Medicine, v. 113, n. 9B, p. 71S-88S, 2002.

KUHNEN, S.; et al. Carotenoid and anthocyanin contents of grains of Brazilian maize landraces. Journal of the Science of Food and Agriculture, v. 91, p. 1548-1553, 2011.

LEMOS, P.M.M; et al. Identificação e quantificação de carotenóides de sementes de variedades locais e crioulas de milho (Zea mays), desenvolvidas e cultivadas tradicionalmente por agricultores familiares de Anchieta (SC). In: REUNIÃO ANUAL DA SBPC, 58. 2006, Florianópolis. Anais... Florianópolis, 2006. (CD-ROM).

MACHADO, A. T, et al. Manejo da diversidade genética do milho e melhoramento participativo em comunidades agrícolas nos estados do Rio de Janeiro e Espírito Santo. Embrapa Cerrados, Planaltina - DF, 2002. 22 p.

MACHADO, A. T, et al. Manejo da diversidade genética de milho em sistemas agroecológicos. Revista Brasileira de Agroecologia, 2007 Vol.1 No.1. p.1349.

MACHADO, A. T., MACHADO, C. T. T., NASS, L. L., Manejo sustentável da agrobiodiversidade nos biomas Cerrado e Caatinga com ênfase em comunidade rurais. Planaltina - DF, 2011a. Brasília: Embrapa.

MACHADO, A. T., MACHADO, C. T. T., NASS, L. L., Manejo da diversidade genética e melhoramento participativo de milho em sistemas agroecológicos. Revista Brasileira de Agroecologia 6 (1): 127-136, $2011 \mathrm{~b}$.

MANGELS, A.R.; et al.Carotenoid content of fruits and vegetables: an evaluation of analytical data. Journal of the american diet association, v. 93, p. 284-296, 1993.

NUNES, J. A., Avaliação participativa de variedades locais e melhoradas de milho visando a eficiência do uso do nitrogênio. Programa de pós-graduação da CAPES, Espírito Santo, 2006. 67p.

PRIMAIZ, Sementes. http://www.primaiz.com.br/produto/pz-316-para-lavouras-com-altoinvestimento. Acesso em 02/11/2013.

RIOS, S. A.; et al. Adaptabilidade e estabilidade de carotenoides em cultivares de milho. In: CONGRESSO NACIONAL DE MILHO E SORGO, 27. Londrina. Agroenergia, produção de alimentos e mudanças climáticas: desafios para milho e sorgo - trabalhos e palestras. [Londrina]: IAPAR; [Sete Lagoas]: Emb Milho Sorgo, 2008.

SOARES, A. C. A multifuncionalidade da agricultura da agricultura familiar. Proposta n'87 2001. p. 43-45. 
SOUZA, W. A., BOAS, O. M. G. da C. V. A deficiência de vitamina A no Brasil: Um panorama. Rev. Panamericana de Salud Pública, Washington, 2002. v. 12, n. 3, p. 173-179.

VENCOVSKY, R. Herança quantitativa. In: PATERNIANI, E; VIÉGAS, G.P. (Eds). Melhoramento e produção do milho. 2.ed. Campinas: Fund. Cargill. 1987. p. 137-214.

WELTZIEN R., E.; SMITH, M.E.; MEITZNER, L.S.; SPERLING, L. Technical and institutional issues in participatory plant breeding-from the perspective of formal plant breeding: A global analysis of issues, results, and current experience. CGIAR Systemwide Program on Participatory Research and Gender Analysis for Technology Development and Institutional Innovation; Cali: CIAT, 2000. 229 p. 


\section{ANEXOS}

TABELA 9. Dados de extração dos carotenoides totais com a média de absorvância das três extrações e com os teores totais, em quatro cultivares de milho. Brazlândia, DF 2013/2014.

\begin{tabular}{ccccc}
\hline Amostra & Tratamento & Bloco & $\begin{array}{c}\text { Média da Abs de três } \\
\text { extrações (triplicata) }\end{array}$ & $\begin{array}{c}\text { Teor }(\boldsymbol{\mu g} \text { g - } \\
\mathbf{1})\end{array}$ \\
\hline 1 & Sol da Manha & 1 & 0,936859 & 10,85164865 \\
7 & Sol da Manha & 2 & 0,7940275 & 9,19722973 \\
10 & Sol da Manha & 3 & 0,732625 & 8,486003861 \\
2 & Eldorado & 1 & 0,4454415 & 5,159554054 \\
8 & Eldorado & 2 & 0,309162 & 3,581027027 \\
9 & Eldorado & 3 & 0,3779925 & 4,378291506 \\
3 & PZ240 & 1 & 0,4404805 & 5,102090734 \\
5 & PZ240 & 2 & 0,2328195 & 2,696750965 \\
12 & PZ240 & 3 & 0,3433875 & 3,97746139 \\
4 & PZ360 & 1 & 0,461771 & 5,348698842 \\
6 & Z360 & 2 & 0,320873 & 3,716675676 \\
11 & PZ360 & 3 & 0,2894115 & 3,352256757 \\
\hline
\end{tabular}

TABELA 10. Quadrados médios e valor de $\mathrm{F}$ da análise de variância para a característica altura de planta (AP), em quatro cultivares de milho. Brazlândia, DF 2013/2014.

\begin{tabular}{cccc}
\hline FV & GL & QM & Valor de F \\
\hline Repetição & 2 & 0,003 & 1,9577 \\
Tratamento & 3 & 0,088 & 49,7089 \\
Erro & 6 & 0,002 & \\
\hline
\end{tabular}

TABELA 11. Quadrados médios e valor de $\mathrm{F}$ da análise de variância para a característica altura de espiga (AE), em quatro cultivares de milho. Brazlândia, DF 2013/2014.

\begin{tabular}{cccc}
\hline FV & GL & QM & Valor de F \\
\hline Repetição & 2 & 0 & 0,0564 \\
Tratamento & 3 & 0,115 & 19,89 \\
Erro & 6 & 0,012 & \\
\hline
\end{tabular}


TABELA 12. Quadrados médios e valor de $\mathrm{F}$ da análise de variância para a característica peso (PG), em quatro cultivares de milho. Brazlândia, DF 2013/2014.

\begin{tabular}{cccc}
\hline FV & GL & QM & Valor de F \\
\hline Repetição & 2 & 0,4110 & 3,3855 \\
Tratamento & 3 & 28,149 & 144,0168 \\
Erro & 6 & 0,0650 & \\
\hline
\end{tabular}

TABELA 13. Quadrados médios e valor de F da análise de variância para a característica Carotenoides, em quatro cultivares de milho. Brazlândia, DF 2013/2014.

\begin{tabular}{cccc}
\hline FV & GL & QM & Valor de F \\
\hline Repetição & 2 & 3,8820 & 14,7025 \\
Tratamento & 3 & 21,701 & 85,1899 \\
Erro & 6 & 0,2640 & \\
\hline
\end{tabular}

TABELA 14. Quadrados médios e valor de $F$ da análise de variância para a característica comprimento da folha da espiga superior (CF), em quatro cultivares de milho. Brazlândia, DF 2013/2014.

\begin{tabular}{cccc}
\hline FV & GL & QM & Valor de F \\
\hline Repetição & 2 & 0,000704 & \\
Tratamento & 3 & 0,001206 & 2,5833 \\
Erro & 6 & 0,000467 & \\
\hline
\end{tabular}

TABELA 15. Quadrados médios e valor de F da análise de variância para a característica largura da folha da espiga superior (LF), em quatro cultivares de milho. Brazlândia, DF 2013/2014.

\begin{tabular}{cccc}
\hline FV & GL & QM & Valor de F \\
\hline Repetição & 2 & 0,001958 & \\
Tratamento & 3 & 0,031978 & 7,6747 \\
Erro & 6 & 0,004167 & \\
\hline
\end{tabular}

TABELA 16. Quadrados médios e valor de $\mathrm{F}$ da análise de variância para a característica área da folha da espiga superior (AF), em quatro cultivares de milho. Brazlândia, DF 2013/2014.

\begin{tabular}{cccc}
\hline FV & GL & QM & Valor de F \\
\hline Repetição & 2 & 0,005187 & \\
Tratamento & 3 & 0,040978 & 7,5189 \\
Erro & 6 & 0,054500 & \\
\hline
\end{tabular}


TABELA 17. Quadrados médios e valor de $\mathrm{F}$ da análise de variância para a característica número de folhas acima da espiga superior (NFS), em quatro cultivares de milho. Brazlândia, DF 2013/2014.

\begin{tabular}{cccc}
\hline FV & GL & QM & Valor de F \\
\hline Repetição & 2 & 0,010833 & \\
Tratamento & 3 & 0,054167 & 13,00 \\
Erro & 6 & 0,041670 & \\
\hline
\end{tabular}

TABELA 18. Quadrados médios e valor de $\mathrm{F}$ da análise de variância para a característica número total de folhas (NF), em quatro cultivares de milho. Brazlândia, DF $2013 / 2014$.

\begin{tabular}{cccc}
\hline FV & GL & QM & Valor de F \\
\hline Repetição & 2 & 0,910833 & \\
Tratamento & 3 & 0,608889 & 1,5896 \\
Erro & 6 & 0,38305 & \\
\hline
\end{tabular}

TABELA 19. Quadrados médios e valor de $F$ da análise de variância para a característica quantidade de nós na planta (NOS), em quatro cultivares de milho. Brazlândia, DF $2013 / 2014$.

\begin{tabular}{cccc}
\hline FV & GL & QM & Valor de F \\
\hline Repetição & 2 & 0,090033 & \\
Tratamento & 3 & 0,124900 & 0,5969 \\
Erro & 6 & 0,209233 & \\
\hline
\end{tabular}

TABELA 20. Quadrados médios e valor de F da análise de variância para a característica quantidade de espigas por planta (NESP), em quatro cultivares de milho. Brazlândia, DF 2013/2014.

\begin{tabular}{cccc}
\hline FV & GL & QM & Valor de F \\
\hline Repetição & 2 & 0,010833 & \\
Tratamento & 3 & 0,153333 & 7,36 \\
Erro & 6 & &
\end{tabular}

TABELA 21. Quadrados médios e valor de $F$ da análise de variância para a característica diâmetro do colmo (DC), em quatro cultivares de milho. Brazlândia, DF 2013/2014.

\begin{tabular}{cccc}
\hline FV & GL & QM & Valor de F \\
\hline Repetição & 2 & 0,002500 & \\
Tratamento & 3 & 0,036667 & 4,00 \\
Erro & 6 & 0,009167 & \\
\hline
\end{tabular}


TABELA 22. Quadrados médios e valor de $\mathrm{F}$ da análise de variância para a característica comprimento do pendão da planta $(\mathrm{CP})$, em quatro cultivares de milho.

Brazlândia, DF 2013/2014.

\begin{tabular}{cccc}
\hline FV & GL & QM & Valor de F \\
\hline Repetição & 2 & 0,001196 & \\
Tratamento & 3 & 0,001175 & 4,4063 \\
Erro & 6 & 0,000267 & \\
\hline
\end{tabular}

TABELA 23. Quadrados médios e valor de F da análise de variância para a característica número de ramificações do pendão (NR), em quatro cultivares de milho. Brazlândia, DF 2013/2014.

\begin{tabular}{cccc}
\hline FV & GL & QM & Valor de F \\
\hline Repetição & 2 & 0,227500 & \\
Tratamento & 3 & 32,67222 & 758,9366 \\
Erro & 6 & 0,043050 & \\
\hline
\end{tabular}

TABELA 24. Quadrados médios e valor de F da análise de variância para a característica posição da espiga ereta (ERET), em quatro cultivares de milho. Brazlândia, DF 2013/2014.

\begin{tabular}{cccc}
\hline FV & GL & QM & Valor de F \\
\hline Repetição & 2 & 28,145833 & \\
Tratamento & 3 & 5368,998611 & 516,4013 \\
Erro & 6 & 10,39695 & \\
\hline
\end{tabular}

TABELA 25. Quadrados médios e valor de F da análise de variância para a característica posição da espiga decumbente (DECUMB), em quatro cultivares de milho. Brazlândia, DF 2013/2014.

\begin{tabular}{cccc}
\hline FV & GL & QM & Valor de F \\
\hline Repetição & 2 & 0,162925 & \\
Tratamento & 3 & 0,9432000 & 6,858 \\
Erro & 6 & 0,1375330 & \\
\hline
\end{tabular}

TABELA 26. Quadrados médios e valor de $F$ da análise de variância para a característica posição da espiga pendente (PEND), em quatro cultivares de milho. Brazlândia, DF 2013/2014.

\begin{tabular}{cccc}
\hline FV & GL & QM & Valor de F \\
\hline Repetição & 2 & 0,2275 & \\
Tratamento & 3 & 53,4900 & 611,3143 \\
Erro & 6 & 0,87500 & \\
\hline
\end{tabular}


TABELA 27. Valores médios de peso hectolitro de quatro cultivares de milho. Brazlândia, DF 2013/2014.

\begin{tabular}{lc}
\hline GENÓTIPOS & PESO EM \\
GRAMAS \\
\hline Sol da manhã & 784.5 \\
Eldorado & 656.2 \\
PZ 240 & 698.7 \\
PZ 316 & 739.8 \\
\hline
\end{tabular}

TABELA 28. Valores médios de número de grãos de quatro cultivares de milho. Brazlândia, DF 2013/2014.

\begin{tabular}{lc}
\hline GENÓTIPOS & QUANTIDADE \\
\hline Sol da manhã & 346 \\
Eldorado & 248 \\
PZ 240 & 312 \\
PZ 316 & 276 \\
\hline
\end{tabular}

TABELA 29. Valores médios de número de grãos em $100 \mathrm{~g}$ de quatro cultivares de milho. Brazlândia, DF 2013/2014.

\begin{tabular}{lc}
\hline GENÓTIPOS & QUANTIDADE \\
\hline Sol da manhã & 346 \\
Eldorado & 248 \\
PZ 240 & 312 \\
PZ 316 & 276 \\
\hline
\end{tabular}

TABELA 30. Valores médios de peso de 20 espigas (média) de quatro cultivares de milho. Brazlândia, DF 2013/2014 .

\begin{tabular}{lc}
\hline GENÓTIPOS & PESO EM \\
KILOGRAMAS \\
\hline Sol da manhã & 4.91 \\
Eldorado & 4.95 \\
PZ 240 & 6.8 \\
PZ 316 & 5.95
\end{tabular}

TABELA 31. Valores médios de comprimento de espigas de quatro cultivares de milho. Brazlândia, DF 2013/2014.

\begin{tabular}{lc}
\hline & TAMANHO EM \\
GENÓTIPOS & Cm \\
\hline Sol da manhã & 18.05 \\
Eldorado & 18.18 \\
PZ 240 & 17.59 \\
PZ 316 & 20.07 \\
\hline
\end{tabular}

